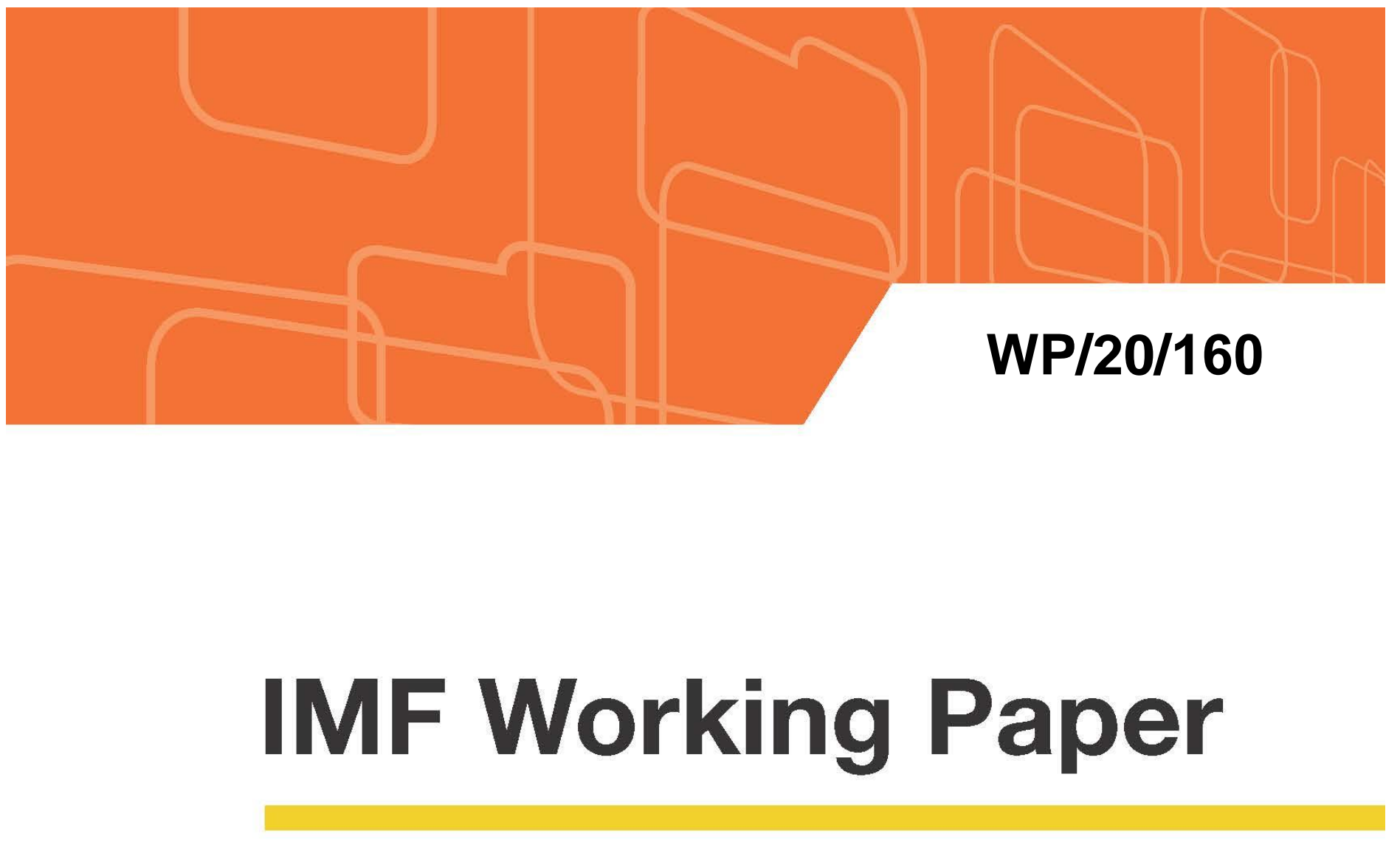

\title{
Monetary Policy and Intangible Investment
}

by Robin Döttling and Lev Ratnovski

IMF Working Papers describe research in progress by the author(s) and are published to elicit comments and to encourage debate. The views expressed in IMF Working Papers are those of the author(s) and do not necessarily represent the views of the IMF, its Executive Board, or IMF management.

I N T E R N A T I O N A L M O N E T A R Y F U N D 


\title{
IMF Working Paper
}

\author{
Research Department
}

\section{Monetary Policy and Intangible Investment*}

\section{Prepared by by Robin Döttling and Lev Ratnovski}

Authorized for distribution by Maria Soledad Martinez Peria

August 2020

\begin{abstract}
IMF Working Papers describe research in progress by the author(s) and are published to elicit comments and to encourage debate. The views expressed in IMF Working Papers are those of the author(s) and do not necessarily represent the views of the IMF, its Executive Board, or IMF management.
\end{abstract}

\begin{abstract}
We contrast how monetary policy affects intangible relative to tangible investment. We document that the stock prices of firms with more intangible assets react less to monetary policy shocks, as identified from Fed Funds futures movements around FOMC announcements. Consistent with the stock price results, instrumental variable local projections confirm that the total investment in firms with more intangible assets responds less to monetary policy, and that intangible investment responds less to monetary policy compared to tangible investment. We identify two mechanisms behind these results. First, firms with intangible assets use less collateral, and therefore respond less to the credit channel of monetary policy. Second, intangible assets have higher depreciation rates, so interest rate changes affect their user cost of capital relatively less.
\end{abstract}

JEL Classification Numbers: E22, E52, G32

Keywords: Intangible Investment, Monetary Policy, Stock Returns, Heterogeneity.

Author’s E-Mail Address: doettling@rsm.nl; lratnovski@imf.org

\footnotetext{
${ }^{*}$ We are grateful to Dalida Kadyrzhanova and Camelia Minoiu for substantial contribution in the early stages of this project. We thank for helpful comments and suggestions Michael Ehrmann, Albert-Jan Hummel, Marek Jarocinski, Luc Laeven, Peter Karadi, Alberto Martin, Felix Ward, as well as seminar participants at the ECB, the Bank of Portugal, and Tinbergen Institute Macro Research Day. Francesca Caucci and Anna Stelzer provided excellent research assistance. The views expressed in the paper are those of the authors and do not represent those of the ECB.
} 


\section{Introduction}

Technological progress and the transition to a service economy have increased the importance of corporate intangible assets. Intangible investment - that in intellectual property, organizational structure, business strategy, and brand equity - was under half of tangible investment in the 1970s, and now exceeds tangible investment (Corrado and Hulten, 2010). This paper asks how the rise of corporate intangible assets affects the effectiveness of monetary policy.

Our headline result is that intangible investment responds less to monetary policy compared to tangible investment. We detail this pattern using two empirical approaches. First, we document that the stock prices of firms with more intangible assets respond less to monetary policy shocks identified from movements in Fed Funds futures around FOMC announcements. Second, we examine the response of corporate investment to interest rates in instrumental variable local projections on both aggregate and firm-level data. Consistent with the stock market results, intangible investment responds less to monetary policy compared to tangible investment, and the total investment in firms with more intangible assets responds less to monetary policy.

We examine three factors that may explain the weaker response of intangible investment to monetary policy. First, intangible assets have low collateral values, so firms with more intangible assets use less secured funding (Rampini and Viswanathan, 2013). This attenuates the standard amplification mechanism where monetary policy affects collateral values and hence the debt capacity of financially constrained firms (Kiyotaki and Moore, 1997). Consistent with this channel, the weaker stock price and investment response to monetary policy in firms with more intangible assets is most pronounced among financially constrained firms. This result holds across a wide variety of measures of firm financial constraints: low age, high cash holdings, and the delaycon measure of Hoberg and Maksimovic (2015) that is based on the textual analysis of firm financial statements. The weaker response to monetary policy of total investment in firms with intangible assets leads, on the aggregate, to a weaker response of intangible investment, which is particularly pronounced among financially constrained firms.

The second factor is that intangible assets have higher depreciation rates. Consequently, same interest rate changes imply proportionately smaller changes to their user cost of capital (Crouzet and Eberly, 2019). Consistent with this channel, we document that the weaker stock price and investment response to monetary policy in firms with intangible assets is more pronounced among firms with a wider gap between tangible and intangible asset depreciation rates. On the aggregate, this also contributes to a weaker response of intangible 
investment, particularly among firms with a wider depreciation gap.

Finally, intangible investment may respond less to monetary policy because of higher investment adjustment costs. Intangible assets are often firm-specific. Thus, they cannot be purchased, but need to be built over a period of time. Moreover, the creation of intangible assets requires skilled human capital that is costly to hire and fire (Sun and Xiaolan, 2019; Döttling et al., 2020). Peters and Taylor (2017) confirm that intangible capital adjusts slower than tangible capital to changes in investment opportunities, consistent with higher investment adjustment costs. Unfortunately, there is no systematic data on the relative adjustment costs of tangible and intangible investment. Using the estimates of adjustment costs for tangible investment (Hall, 2004; Kim and Kung, 2017), we find that tangible investment with higher adjustment costs reacts more to monetary policy. ${ }^{1}$ Extrapolating this finding to the comparison of tangible and intangible investment suggests that the higher adjustment costs of intangible investment unlikely contribute to its weaker response to monetary policy.

A key challenge is measuring intangible capital. While tangible investment is reported as such in firm financial statements, and a firm's tangible capital stock reported as property, plant and equipment, most intangible investment is expensed. We follow the literature in classifying certain expenditure streams as intangible investment, on both aggregate and firm-level data. Aggregate intangible investment is sourced from the National Income and Product Accounts (NIPA Tables) of the U.S. Bureau of Economic Analysis (BEA). These data cover all U.S. establishments and include investment in R\&D, software, and artistic originals. For firm-level intangible investment, we use the Compustat-based measure of Peters and Taylor (2017). These data cover U.S. public firms, and includes investment in research and development (R\&D) and in organization capital, captured as a share of selling, general, and administrative expenses (SG\&A, cf. Eisfeldt and Papanikolaou, 2013). Figure 1 plots the evolution of the intangible-to-total asset and investment ratios in aggregate and firm-level data. The firm-level measure exhibits a higher level of these ratios, consistent with its broader definition of intangible assets and its focus on more technological and complex large firms. Yet, the aggregate and the firm-level measures display a similar upward trend, which points to a growing importance of intangible assets and investment in the U.S. economy.

In the stock price response analysis we identify monetary policy shocks using high-frequency movements in Fed Funds futures around FOMC announcements, following Kuttner (2001), Bernanke and Kuttner (2005),

\footnotetext{
${ }^{1}$ This is consistent with the findings that investment with high adjustment costs responds negatively to uncertainty (Majd and Pindyck, 1985; Bloom, 2009), whereas uncertainty responds positively to interest rate shocks (Bekaert et al., 2013). Consequently, monetary accommodation (tightening) has additional stimulative (restrictive) effects on investment with high adjustment costs by reducing (increasing) uncertainty.
} 
and Gurkaynak, Sack, and Swanson (Gurkaynak et al.). We document that the stock prices of firms with more intangible assets respond less to monetary policy shocks. A one standard deviation increase in the intangible-to-total asset ratio is associated with a $45 \mathrm{bp}$ smaller stock price response to a $1 \%$ increase in the Fed Funds rate, corresponding to about one-tenth of a sample average response. The same increase in the intangible-to-total asset ratio is associated with an up to $1.1 \%$ smaller stock price response among financially constrained firms, and a 65bp smaller response among firms with a large difference between the tangible and intangible asset depreciation rates. The regressions include a rich set of time-varying firm-level controls, including proxies of financial constraints. Furthermore, we saturate the regressions with granular 4-digit NAICS industry $\times$ time, firm, and fiscal quarter fixed effects to control for time-varying industry-level dynamics, time-invariant firm characteristics, and seasonality. Finally, we measure stock price returns using both raw returns and abnormal returns that control for a firm's beta, thus capturing the firm's systematic risk and cyclically. In these ways, we ensure that our results are not driven by a differential monetary policy reaction depending on firm financial constraints, other firm characteristics, or a firm's exposure to the business cycle.

To study the dynamic response of investment to monetary policy, we use the local projections approach of Jordà (2005) and instrument the interest rate using cumulative high-frequency shocks, similar to Gertler and Karadi (2015). Consistently across aggregated and firm-level data, intangible investment reacts less to monetary policy compared to tangible investment. A 25bp increase in the instrumented 1-year Treasury rate is associated with a tangible investment decline that peaks after 12 quarters at $2.2 \%$ to $4 \%$ in aggregate and firm-level data, respectively. In contrast, intangible investment declines by only $0.75 \%$. Moreover, in the cross section, firms with more intangible assets reduce their total investment less in response to a monetary policy tightening. A one standard deviation increase in the intangible-to-total asset ratio is associated with a $20 \%$ smaller total investment response, consistent with the stock price response results. The same increase in the intangible-to-total asset ratio is associated with a $38 \%$ smaller investment response in financially constrained firms, and a $24 \%$ smaller response in firms with a large difference in the tangible and intangible asset depreciation rates.

This paper brings together two growing strands of literature. The first strand of the literature focuses on the secular rise of corporate intangible capital over the last five decades (Corrado et al., 2009; Corrado and Hulten, 2010; Corrado et al., 2016). The literature documents how intangible capital affects productivity growth (Corrado et al., 2017) and firm behavior. On the asset side, intangible capital has a higher user cost 
(Crouzet and Eberly, 2019) and lowers the Q-sensitivity of firm investment (Peters and Taylor, 2017). On the liability side, intangible capital constrains firm debt capacity (Bates et al., 2009; Falato et al., 2018) while also lowering demand for external funds (Döttling et al., 2020). We bring the asset- and liability-side effects together and document how the lower collateral value and the higher user cost of capital of intangible assets explain the muted response of intangible investment to monetary policy.

The second strand is the literature on the heterogeneity in investment response to monetary policy. This literature documents that investment responds to monetary policy more in financially constrained firms, across a variety of proxies of financial constraints: firm size (Kashyap et al., 1994; Gertler and Gilchrist, 1994; Kashyap and Stein, 1995), age (Cloyne et al., 2018), cash and leverage (Jeenas, 2018b), and distance to default (Ottonello and Winberry, 2018). We contribute to this literature by documenting a novel source of heterogeneity in investment response, namely that between tangible and intangible investment, controlling for all traditional proxies of firm financial constraints. In a related paper, Caggese and Pérez-Orive (2020) develop a model where lower interest rates reduce the income on corporate savings, disadvantaging firms with intangible assets that invest from internal funds. Consequently, lower interest rates may be less stimulative and even contractionary for these firms, and lead to a misallocation of capital. While we find no evidence that monetary accommodation is contractionary for intangible firms, their model offers an additional reason for a weaker monetary policy response in firms with intangible assets.

This paper proceeds as follows: Section 2 describes the data, Section 3 documents the headline results, Section 4 presents evidence on the credit, depreciation, and adjustment cost channels, and Section 5 concludes.

\section{Data}

\subsection{Measuring Tangible and Intangible Investment}

We source firm-level asset and investment data from quarterly financial statements of public firms in Compustat. Tangible investment and capital stock are reported in firm financial statements as capital expenditures (CAPX) and net property, plant, and equipment (PPENT), respectively. Measuring intangible investment and capital is more challenging. Most intangible investment is expensed, so most of intangible capital does not show up on a firm's balance sheet. We follow Peters and Taylor (2017) and define intangible investment as the sum of research and development (R\&D) expenses and $30 \%$ of selling, general and administrative (SG\&A) expenses. R\&D expenses capture investment in knowledge capital, whereas a share of SG\&A expenses reflects 
investment in brand and organizational capital (Eisfeldt and Papanikolaou, 2013). ${ }^{2}$

Capitalizing intangible investment using depreciation rate estimates from Li and Hall (2016) and adding on-balance sheet intangibles (mostly goodwill) obtains a measure of intangible capital stock. We take this measure directly from Peters and Taylor (2017) through Wharton Research Data Services. Their measure is annual, so we interpolate it linearly into a quarterly measure. In robustness, we use an alternative intangible capital stock estimate from Ewens et al. (2019), who use acquisition prices to more accurately estimate depreciation rates and the share of SG\&A expenditure that contributes to intangible capital formation, and obtain very similar results.

Following sampling procedures standard in the corporate finance literature, we exclude financial firms (SIC codes 4900 - 4999), utilities (SIC codes 6000 - 6999) and government (SIC codes 9000 and above). We also exclude firms with missing or negative assets or sales, negative CAPX, R\&D, or SG\&A expenditure, and very small firms with physical capital under $\$ 5$ million. This leaves us with 8938 unique firms and 318305 firm-quarter observations between 1991 and 2016. We deflate all data using the CPI and express all variables in real 1990 U.S. Dollars.

Next to firm-level data, we source aggregate corporate asset and investment data from BEA National Income and Product Accounts (NIPA) at quarterly frequency. Total investment is defined as total nonresidential fixed investment. This can be split into tangible investment in structures and equipment, and intangible investment in intellectual property products (IPP). IPP include R\&D, software, and artistic originals. ${ }^{3}$

\subsection{Dynamics of Tangible and Intangible investment}

Compared to the firm-level Compustat-based measure, the aggregate BEA data has a narrower definition of intangible investment that excludes organizational capital. At the same time, BEA data covers all U.S. establishments, while Compustat only covers large public firms. Figure 1 plots the evolution of intangibleto-total asset (panel A) and investment (panel B) ratios in both datasets. Compustat data show higher intangible-to-total asset and investment ratios, consistent with its focus on more technological and complex large firms, and a broader definition of intangible capital. Despite this level difference, firm-level and aggregate data exhibit a remarkably similar upward trend in intangible investment and capital stock.

\footnotetext{
${ }^{2}$ The share of SG\&A invetsment attributed to financial capital in the literature varies from $20 \%$ to $30 \%$ (cf. Falato et al., 2018). Recent estimates from Ewens et al. (2019) suggest an average share of $28 \%$.

${ }^{3}$ NIPA Table 5.3.3 - Real Private Fixed Investment by Type.
} 
Figure 2 compares investment growth rates. Panel A documents a strong similarity in the growth rates of total investment (tangible + intangible) in Compustat and BEA data. Panels B and C decompose BEA and Compustat investment into their tangible and intangible components. In both datasets intangible investment is less volatile than physical investment. This suggests that intangible investment may respond less to macroeconomic shocks such as monetary policy shocks, in line with the results in this paper. Panel D further decomposes Compustat intangible investment into its R\&D and SG\&A components. R\&D investment appears somewhat more volatile than SG\&A, which is still substantially less cyclical than physical investment. Our analysis is robust to focusing on the $\mathrm{R} \& \mathrm{D}$ component of intangible investment only.

\subsection{Other Variables}

Firm-level control variables are sourced from Compustat and include firm age, Tobin's Q, leverage, cash holdings, cashflows, firm size, and a dummy for whether a firm pays a dividend. Daily stock returns data from CRSP are mapped to Compustat using the linking table from Wharton Research Data Services. Table A1 provides variable definitions, and Table 1 presents summary statistics for all firms, and separately for firms with above- and below-median intangible-to-total asset ratios. Consistent with the literature, firms with more intangible assets have a higher Tobin's Q, more cash, lower leverage, and are less likely to pay a dividend (Peters and Taylor, 2017; Falato et al., 2018). Unsurprisingly, firms with more intangible assets have higher intangible investment, while those with more tangible assets have higher physical investment. Beyond this, the two groups of firms are comparable in terms of age, size, and profitability.

We obtain the macroeconomic variables 1-year Treasury rate, CPI, industrial production, and the employment ratio from Federal Reserve Economic Data of the St. Louis Fed. To control for financial conditions, we use excess bond premium from Gilchrist and Zakrajšek (2012). Table A2 lists all aggregate variables, definitions and data sources.

\section{Baseline Results}

This section consists of two parts. The first part documents how stock prices of firms with more intangible assets respond to monetary policy shocks. The second part documents how intangible investment responds to monetary policy compared to tangible investment, and how intangible assets affect a firm's total investment response to monetary policy. 


\subsection{Stock Price Response to Monetary Policy Shocks}

Changes to the U.S. monetary stance are conveyed through Federal Open Market Committee (FOMC) announcements after its regular and ad-hoc meetings. We identify monetary policy shocks using highfrequency movements in Fed Funds futures prices in the 30 minutes window around FOMC announcements, following Kuttner (2001), Bernanke and Kuttner (2005) and Gurkaynak, Sack, and Swanson (Gurkaynak et al.). The identifying assumption is that this narrow window contains no other major information that affects interest rates. The data cover all FOMC meetings from 1991 to $2016 .{ }^{4}$

We then assess firms' stock price response to monetary policy shocks using the following regression specification:

$$
\Delta R E T_{i t}=\beta_{1} \times \Delta F F 4_{t}+\beta_{2} \times X_{i t}+\beta_{3} \times \Delta F F 4_{t} \times X_{i t}+\eta_{j t}+\mu_{i}+\psi_{f q}+\varepsilon_{i t}
$$

where $\triangle R E T_{i t}$ is the stock return of firm $i$ on the day of the FOMC meeting, and $\Delta F F 4_{t}$ is the change in the 3-month ahead Fed Funds futures rate around event date $t . X_{i t}$ are firm characteristics at the end of the previous quarter. These include a firm's intangible ratio, defined as the ratio of intangible-to-total assets. The coefficient on the interaction of the intangible ratio with $\Delta F F 4_{t}$ is the key parameter of interest. It captures whether the stock prices of firms with more intangible assets react differently to monetary policy surprises. Other firm-level controls in $X_{i t}$ are total Q, age, cash holdings, leverage, size, cashflows, and a dummy for whether the firm pays a dividend. These controls capture key firm characteristics, many of which are also common proxies for firm financial constraints.

The model is saturated with 4-digit NAICS industry $\times$ event-date fixed effects $\eta_{j, t}$ that control for any differences across narrowly-defined industries on each announcement date. Furthermore, we report results with and without firm fixed effects $\mu_{i}$ that control for time-invariant firm characteristics. All regression include fiscal-quarter fixed effects $\psi_{f q}$ to control for seasonality. ${ }^{5}$ Standard errors are clustered at the industry and the event-date levels.

In measuring stock returns $\Delta R E T_{i t}$, we consider both raw and abnormal returns. Abnormal returns are estimated from a basic capital asset pricing model over 100 days prior to the FOMC meeting, using the CRSP value-weighted index as market benchmark. Abnormal returns control for a firm's beta, which captures the

\footnotetext{
${ }^{4}$ As common in the literature, we exclude the FOMC meeting on September 17, 2001, which coincided with the market opening following the September 11 terrorist attacks. We thank Peter Karadi for kindly sharing the data.

${ }^{5}$ Fiscal quarters vary across firms and do not necessarily coincide with calendar quarters, depending on a firm's reporting month.
} 
volatility of a stock and its exposure to systematic risk.

\subsubsection{Results}

Table 2 documents the headline results. Column 1 reports an average stock price response of $-4.36 \%$ to a $1 \%$ unexpected increase in the Fed Funds rate. This is similar to $-4.68 \%$ in Bernanke and Kuttner (2005). Columns 2 to 5 include the interactions of $\Delta \mathrm{FF} 4$ with firm characteristics, under different stock returns measures and fixed effects combinations. The main explanatory term of interest is the interaction between $\Delta \mathrm{FF} 4$ and a firm's intangible ratio. The coefficient estimate for this interaction term is stable at between 1.42 and 1.53 across the specifications and consistently significant at the $5 \%$ level. This indicates that the stock price of firms with a higher intangible-to-total capital ratio reacts less to monetary policy surprises. A one-standard deviation increase in the intangible ratio is associated with a 45bp smaller stock price decline in response to a $1 \%$ unexpected increase in the Fed Funds rate.

Interestingly, once we consider abnormal returns (columns 4 and 5), the coefficients on the interactions between $\triangle \mathrm{FF} 4$ and all firm characteristics except the intangible ratio become statistically insignificant or only marginally significant. This suggests that those firm characteristics affect stock price response to monetary policy shocks primarily through their impact on a firm's systematic risk.

\subsubsection{Robustness}

We verify the robustness of the baseline results documented in Table 2 to using alternative measures of monetary policy surprises and of intangible capital. First, we use the Jarocinski and Karadi (2020) decomposition of FF4 shocks into "pure" monetary policy shocks and "central bank information shocks". This controls for the fact that monetary policy announcements communicate not only the monetary policy stance, but also central bank views about the economy. ${ }^{6}$ Table A3 documents the outcome of such decomposition in panel A. Column 1 confirms that pure monetary policy shocks affect stock prices negatively, while central bank information shocks affect stock prices positively, as expected. Columns 2 to 5 verify that the interaction of the intangible ratio with pure monetary policy shocks is positive, with point estimates slightly higher than in the baseline. By contrast, the interaction of the intangible ratio with central bank information shocks is statistically insignificant, confirming that our results are driven by monetary policy shocks rather than the news about economic fundamentals.

\footnotetext{
${ }^{6}$ Jarocinski and Karadi (2020) identify a monetary policy shock from a negative co-movement of Fed Funds futures and stock prices, and a central bank information shock from a positive co-movement.
} 
Second, we replicate the baseline results using an alternative measure of firm intangible capital stock from Ewens et al. (2019). This measure uses acquisition prices to better estimate industry-level intangible capital depreciation rates, and lets the share of SG\&A expenditure that is counted towards intangible investment vary by industry. Panel B of Table A3 documents that the point estimates on the interaction between monetary policy surprises and this alternative measure of firm intangible ratio are similar to those in the baseline.

Overall, our stock return results document that the valuation of firms with more intangible assets respond less to monetary policy shocks, also in specifications with abnormal return that control for the differences in systematic risk across firms.

\subsection{Investment Response}

We now turn to the analysis of the tangible and intangible investment response to monetary policy. We examine aggregate investment response using national accounts data and firm-level response using Compustat data. This helps verify the robustness of the results to alternative firm samples and measures of intangible investment.

\subsubsection{Empirical Strategy}

We measure monetary policy stance as the 1-year Treasury rate. Relative to the Fed Funds rate, the 1-year Treasury rate better captures interest rate variation in the unconventional monetary policy environment during the later part of our time sample, due to its longer maturity. To address the endogeneity of interest rates we instrument the Treasury rate using cumulative FF4 monetary policy shocks. This approach is akin to the PVAR approach in Gertler and Karadi (2015). ${ }^{7}$ The cumulative FF4 measure is a strong instrument for the 1-year Treasury rate, with the F-stat exceeding 37 in the first-stage regression. Figure 3 plots the actual and the instrumented 1-year Treasury rate, along with the FF4 instrument.

To trace out the dynamic impact of monetary policy on firm investment, we use instrumental-variable local projections (LP-IV, Jordà, 2005). That is, for each horizon $h$, we estimate the regression:

$$
y_{t+h, i}-y_{t-1, i}=\beta_{1}^{h} R_{t}+\beta_{2}^{h} X_{t-1}^{m}+\beta_{3}^{h} X_{t-1, i}^{f}+\mu_{i}+\psi_{f q}+\varepsilon_{t, i},
$$

\footnotetext{
${ }^{7}$ Following Gertler and Karadi (2015), Footnote 11, we construct cumulative FF4 shocks by first creating a monthly series that reflects multiple FOMC announcements within a month, and then cumulating that series.
} 
where the outcome variable $y_{t, i}$ is a measure of investment, and $R_{t}$ is the instrumented 1-year Treasury rate. $X_{t-1}^{m}$ are lagged macro control variables: $\log$ CPI, log industrial production, the excess bond premium, and the employment ratio. When estimating local projections on firm-level data, we include firm fixed effects $\mu_{i}$, fiscal-quarter fixed effects $\psi_{f q}$, and all firm-level controls $X_{t-1, i}^{f}$ from the stock returns regression (1). The regression specification for aggregate data only includes macro controls and calendar quarter fixed effects:

$$
y_{t+h}-y_{t-1}=\alpha+\beta_{1}^{h} R_{t}+\beta_{2}^{h} X_{t-1}^{m}+\psi_{c q}+\varepsilon_{t} .
$$

We present the results in the form of impulse response functions (IRFs) that plot the coefficients $\beta_{1}^{h}$ for quarterly horizons $h=1 \ldots 20$, along with a $95 \%$ confidence interval.

Verification Figure A1 verifies that the response of standard macroeconomic variables to a monetary policy shock in our setup is in line with that documented in the literature. In response to a 25bps increase in the instrumented 1-year Treasury rate, CPI drops by $0.2-0.3 \%$ (somewhat stronger than $-0.15 \%$ in Gertler and Karadi (2015)), employment drops by $0.2 \%$ (similar to $-0.25 \%$ in Cloyne et al. (2018)), excess bond premium increases by 10 bps (similar to Gertler and Karadi (2015)), industrial production drops by $0.7 \%$ (similar to the $0.6 \%$ in Cloyne et al. (2018)), and aggregate business investment drops by $2 \%$ (in line with Cloyne et al. (2018)).

\subsubsection{Evidence from Firm-Level Data}

In firm-level data, we consider as outcome variables the tangible, intangible, and total investment rates, defined as: ${ }^{8}$

\footnotetext{
${ }^{8}$ We winsorize investment rates at the $1 \%$ level. Their summary statistics presented in Table 1 are in line with the annual investment rates in Peters and Taylor (2017).
} 


$$
\begin{aligned}
I_{t}^{\text {tan }} & =\frac{C A P X_{t}}{P P E_{t-1}} \\
I_{t}^{i n t} & =\frac{R \& D_{t}+0.3 \times S G \& A_{t}}{K_{t-1}^{i n t}} \\
I_{t}^{t o t} & =\frac{C A P X_{t}+R \& D_{t}+0.3 \times S G \& A_{t}}{K_{t-1}^{i n t}+P P E_{t-1}}
\end{aligned}
$$

where $K_{t}^{i n t}$ is the intangible capital stock estimate from Peters and Taylor (2017) and $P P E_{t}$ is tangible capital measured as net property plant and equipment.

Figure 4 plots the response of log investment rates to an instrumented 25bp increase in the 1-year Treasury rate. Panel A documents that the firm-level total investment rate drops by $2 \%$ after 8-12 quarters, in line with the response of aggregate business investment in Figure A1. We further proceed to decompose this effect into the differential response of tangible and intangible investment, along two dimensions. First, we consider total investment response in firms with more tangible and more intangible assets. Second, we consider tangible and intangible investment response within a firm.

Panel B documents the response of total investment separately for tangible and intangible firms, defined as those with below- and above median intangible-to-total capital, respectively. The response of total investment is substantially weaker among firms with more intangible assets. In response to an instrumented 25bp increase in the Treasury rate, firms with a below-median intangible ratio reduce their total investment by up to $3 \%$ after 10-12 quarters. By contrast, firms with an above-median intangible ratio reduce their total investment by less than one percent. The weaker investment response to monetary policy in intangible firms is consistent with our earlier results (Table 2) on the weaker stock market response to monetary policy shocks for these firms.

Panels C and D compare the effects of monetary policy on a firm's tangible and intangible investment, by decomposing total investment into its tangible and intangible components. The vast majority of the investment response comes from tangible investment. In response to an instrumented 25bp increase in the Treasury rate, it declines by about $4 \%$ after 12 quarters. By contrast, intangible investment declines by only $0.7 \%$.

To further compare the effects documented in panels $\mathrm{C}$ and $\mathrm{D}$, panel $\mathrm{E}$ plots the log response of the ratio of a firm's tangible over intangible investment. A drop in this ratio indicates a stronger response of tangible compared to intangible investment, and estimating the response of this ratio to monetary policy allows 
testing whether the difference in the response of tangible compared to intangible investment is statistically significant. The ratio falls by up to $3 \%$, statistically different from zero with $95 \%$ confidence. In panel $\mathrm{F}$, the ratio of tangible investment (CAPX) to $\mathrm{R} \& \mathrm{D}$ exhibits a similar response. The narrower measure of intangible investment omits SG\&A expenditure and is closer to the intangible investment measure in the national accounts data, confirming that the result is robust to considering only the R\&D component of intangible investment.

A more rigorous way to assess the effects of a firm's intangible ratio on its investment (complementing the sample split in panel B of Figure 4) is to enrich the local projections specification (2) with interaction terms between the 1-year Treasury rate and firm characteristics, $\beta_{4}^{h} R_{t} X_{t-1, i}^{f}$ :

$$
y_{t+h, i}-y_{t-1, i}=\beta_{1}^{h} R_{t}+\beta_{2}^{h} X_{t-1}^{m}+\beta_{3}^{h} X_{t-1, i}^{f}+\beta_{4}^{h} R_{t} X_{t-1, i}^{f}+\mu_{i}+\eta_{t}+\psi_{f q}+\varepsilon_{t, i} .
$$

The resulting structure mirrors the stock returns specification (1) of Section 3.1. The coefficients in $\beta_{4}^{h}$ capture how firm characteristics affect a firm's investment response to monetary policy. By controlling for interactions with other firm characteristics, this specification allows us to isolate the effects of a firm's intangible ratio on its investment response from the effects of other firm characteristics (for example, the summary statistics in Table 1 show that intangible firms have lower leverage and more cash). Moreover, since this specification focuses on identifying the interaction term, we can include time fixed effects $\eta_{t}$ to control for any time-varying macroeconomic conditions that influence all firms.

Table 3 documents the response of the log total investment rate to monetary policy for horizons $h=8$ and $h=12$ quarters (the horizons at which the impulse response functions demonstrate the strongest investment response). The interaction term between the intangible ratio and the 1-year Treasury rate is positive and statistically significant (columns 2 and 5), also when including time fixed effects (columns 3 and 6 ). A one standard deviation increase in the intangible-to-tangible asset ratio reduces a firm's total investment response to a $25 \mathrm{bp}$ increase in the 1-year Treasury rate by about $40 \mathrm{bp}$, corresponding to almost a fifth of the average investment response of $2 \%$. This strong attenuating effect is consistent with the sample splits in Panel B of Figure 4.

Overall, the results based on firm-level data show that intangible investment reacts less to monetary policy compared to tangible investment, and that, consistent with this, total investment in firms with more intangible assets reacts less to monetary policy. 


\subsubsection{Evidence from Aggregate Data}

Firm-level Compustat data only capture public firms. By contrast, national accounts data cover all establishments. Further, the BEA employs a different definition of intangible investment based on intellectual property products (IPP: R\&D, software, and artistic originals), which excludes SG\&A expenditure that contributes to organizational capital. Replicating our firm-level investment response results on aggregate data therefore verifies their robustness to an alternative data source, a wider establishment sample, and a different measure of intangible investment.

Figure 5 plots the response of log tangible investment to monetary policy based on BEA NIPA data. In response to an instrumented 25bp increase in the 1-year Treasury rate, tangible investment (structures and equipment) declines by about $2.2 \%$ after 12 quarters (panel A), somewhat less than the $4 \%$ decline observed in firm-level data. Intangible investment (IPP) declines by $0.75 \%$ (panel B), similar to the effect in firm-level data. Total investment declines by less than $2 \%$ (panel $\mathrm{C}$ ). In panel $\mathrm{D}$, the drop in the ratio of tangible over intangible ratio reaches $1.5 \%$, indicating a statistically significantly stronger response of tangible compared to intangible investment. The findings based on aggregate data are therefore consistent with the baseline firm-level results that intangible investment responds less to monetary policy compared to tangible investment.

\section{Why Does Intangible Investment React Less?}

Why may monetary policy affect intangible investment and firms with intangible assets less? This section discusses and tests three candidate mechanisms. The first mechanism is a "credit channel": firms with more intangible assets are less reliant on secured debt funding. Therefore, the standard amplification mechanism of monetary policy where it affects collateral values and the intensity of external finance constraints is muted for these firms. The second mechanism is a "depreciation channel": intangible assets have higher depreciation rates than tangible assets. Therefore, same interest changes may affect their user cost of capital proportionately less. The third mechanism is the "adjustment cost channel": intangible investment is costlier to scale up and down compared to tangible investment. We offer evidence consistent with the credit and the depreciation channels, while existing indirect evidence cannot support the adjustment cost channel. 


\subsection{Credit Channel}

The credit channel of monetary policy acts on firm investment by affecting the price and volume of credit available to firms. The volume of available credit is determined by the collateral value of firm assets (Kiyotaki and Moore, 1997; Bernanke et al., 1999). ${ }^{9}$ Intangible assets have lower collateral value compared to tangible assets. ${ }^{10}$ Consequently, while monetary policy still affects the price of credit, it has a smaller effect on the volume of credit for firms with more intangible assets, because these firms rely less on secured credit to start with.

Formally, consider a profit-maximizing firm that chooses its investment at date $t$. The firm has initial capital stock $K_{t}$ and internal funds (cash) $A_{t}$. It decides how much debt $D_{t}$ to raise in order to make an investment $I_{t}=A_{t}+D_{t}$, resulting in capital stock $K_{t+1}=K_{t}+I_{t}$ at $t+1$. Capital produces $F\left(K_{t+1}\right)$, where $F^{\prime}(K) \geq 0$ and $F^{\prime \prime}(K) \leq 0$. The cost of borrowing and the firm's alternative cost of using internal funds are the interest rate $r_{t}$.

Importantly, the firm is subject to a collateral constraint:

$$
D_{t} \leq(1-\mu) Q_{t}\left(r_{t}\right) K_{t}
$$

Here, $Q_{t}\left(r_{t}\right)$ is the collateral value of capital, which declines in the interest rate $r_{t}: Q_{t}^{\prime}\left(r_{t}\right)<0$. The parameter $\mu$ captures the share of the capital stock that is intangible and thus cannot be pledged as collateral. The empirical counterpart of $\mu$ in our analysis is the intangible-to-total assets ratio.

\footnotetext{
${ }^{9}$ Here, collateral reflects either de-jure collateral for a specific loan, or the liquidation value of firm assets. While firms have some access to unsecured credit, the collateral value of firm assets remains a major external finance constraint. In a 2015 survey by the Bank of England, banks respond that 90\% of their loans are secured by some form of collateral (Haskel, 2020). Similarly, Rampini and Viswanathan (2013) document that U.S. firms' aggregate liabilities are lower than their tangible assets, and argue that therefore the vast majority of credit is explicitly or implicitly backed by collateral. Evidence in Bahaj et al. (2020) highlights the importance of the collateral value of a director's house for firm investment.

${ }^{10}$ The reason is that intangible assets are often more firm-specic and more difficult to value and liquidate than tangible assets. For example, the value of a partially-developed technology is likely to be intrinsically linked with the human capital of the researchers who work on it. It is difficult to transfer ownership of such an asset, or to seize it. A creditor that attempts to resell this asset would likely recoup only a fraction of its original value. Empirical studies find strong evidence that firms finance intangible assets primarily through equity or internal funds (Carpenter and Petersen, 2002; Bates et al., 2009; Brown et al., 2009, 2013; Falato et al., 2018). While some intangible assets, notably patents, can be used as collateral (Loumioti, 2012; Mann, 2018), this practice is not prevalent. Dell'Ariccia et al. (2020) confirm that patents do not fully ameliorate external finance frictions caused by the low collateral value of intangible assets.
} 
The firm's optimization program is:

$$
\begin{array}{ll}
\max _{I_{t}, D_{t}} & F\left(K_{t+1}\right)-I_{t} r_{t} \\
\text { s.t. } & K_{t+1}=K_{t}+I_{t}, \\
& I_{t}=A_{t}+D_{t}, \\
& D_{t} \leq(1-\mu) Q_{t}\left(r_{t}\right) K_{t} .
\end{array}
$$

Solving the optimization problem gives two solution regions, depending on whether the collateral constraint (5) binds. An unconstrained firm matches the marginal product of capital to its opportunity cost $r_{t}$. Its investment $I_{t}$ is chosen such that $F^{\prime}\left(K_{t+1}\right)=r_{t}$. Investment declines in the interest rate because $F^{\prime \prime}\left(K_{t+1}\right) \leq 0$, representing the effect of monetary policy on the hurdle rate of investment. Note that the share of intangible assets in total capital $\mu$ does not affect the investment of a firm that is unconstrained by the collateral value of its assets.

By contrast, the investment of a constrained firm is given by $I_{t}=(1-\mu) Q_{t}\left(r_{t}\right) K_{t}+A_{t}$, with

$$
\frac{d I_{t}}{d r_{t}}=(1-\mu) Q_{t}^{\prime}\left(r_{t}\right) K_{t}
$$

Here, investment is limited by the collateral value of firm assets, which declines in the interest rate: $Q_{t}^{\prime}\left(r_{t}\right)<0$. Importantly, investment declines in the interest rate less for firms with a higher share of intangible assets in total capital $\mu$, because such firms use less secured funding. Intuitively, fluctuations in collateral values have little effect on the funding constraints of firms that cannot pledge their assets as collateral anyway.

This stylized model of intangible assets and the credit channel of monetary policy thus yields the following testable prediction: (1) firms with a higher ratio of intangible assets adjust their investment less in response to monetary policy, (2) but only to the extent that such firms are financially constrained. Whereas our baseline results confirm that firms with more intangible assets indeed respond less to monetary policy, in this section we document that this muted reaction is driven primarily by financially constrained firms, consistent with the credit channel outlined above. 


\subsubsection{Measuring Financial Constraints}

The literature offers two approaches to identify firm financial constraints. One approach uses firm characteristics that correlate with financial constraints. Such characteristics include low firm age, as younger firms have less well established access to financial markets (Hadlock and Pierce, 2010; Cloyne et al., 2018), or high cash holdings that indicate precautionary liquidity hoarding (Jeenas, 2018a). Another approach identifies financial constraints from the textual analysis of firm financial statements, by assessing the frequency of language that indicates investment delays due to a lack of financing capacity, such as the delaycon measure of Hoberg and Maksimovic (2015). ${ }^{11}$ Either approach is imperfect (Farre-Mensa and Ljungqvist, 2016), and the correlation between different measures of financial constraints is modest at about 0.12-0.16 (see Table A4). We therefore document the results using both approaches to measuring financial constraints and, reassuringly, obtain results that are consistent across all measures.

\subsubsection{Stock Price Response}

To assess whether the weaker stock price response to monetary policy in firms with more intangible assets is more pronounced among financially constrained firms, we re-run the baseline regressions from Table 2, while splitting the sample into more and less financially constrained firms. All regressions include the same controls and fixed effects as in the baseline.

Table 4 documents the estimated coefficient on the interaction term $\Delta \mathrm{FF} 4 \times$ Intangible Ratio. Panel A splits the sample into young firms, defined as those in the lowest age tercile in a given quarter, and old firms in the top age tercile. For young firms (columns 1 and 2), the coefficient estimates are between 3.08 and 3.64, more than twice the full-sample estimate of around 1.5 in Table 2. These estimates imply that, for young firms, a one standard deviation increase in the intangible ratio leads to a $0.9-1.1 \%$ smaller stock price decline in response to a $1 \%$ unanticipated increase in the Fed Funds rate, as compared to a $0.45 \%$ smaller decline in the full sample. For old firms (columns 3 and 4), the coefficient estimates are between 0.25 and 0.7: smaller than the full-sample estimates and statistically insignificant. ${ }^{12}$

Panel B splits the sample into firms with high and low cash holdings, defined as, respectively, firms in the

\footnotetext{
${ }^{11}$ Hoberg and Maksimovic (2015) identify a set of constrained firms that discuss investment delays due to liquidity problems in their annual reports. The continuous delaycon measure is constructed by scoring how proximate a firm's wording in the liquidity and capitalization section is to constrained firms that delay investment.

${ }^{12}$ The coefficient estimates for the firms in the middle age tercile are in-between those for the young and the old firms, and similar to the full-sample estimates. See Table A5 for the complete set of results.
} 
top tercile and bottom two terciles in the cash-to-assets ratio in a given quarter. ${ }^{13}$ For firms with high cash holdings (columns 1 and 2), the coefficient estimates on the interaction term between $\Delta \mathrm{FF} 4$ and a firm's intangible ratio are between 2.55 and 2.78. These are higher than the full-sample estimates and significant at the $1 \%$ level despite the smaller sample size. For firms with low cash holdings (columns 3 and 4 ), the coefficient estimates are again substantially smaller and statistically insignificant.

Panel C splits the sample based on the textual analysis-based measure of firm financial constraints. We define financially constrained firms as those with an above-median delaycon measure of Hoberg and Maksimovic (2015) in a given quarter. Consistent with the age and cash results, the coefficient estimates on the interaction interaction term between $\Delta \mathrm{FF} 4$ and a firm's intangible ratio are between 2.25 and 2.66 , larger than the full-sample estimates. The difference between constrained and unconstrained firms is the strongest - with 9 times different coefficient estimates - for abnormal stock returns. The difference is smaller for raw returns, owing to an imprecisely estimated coefficient in less constrained firms. ${ }^{14}$

Overall, the results based on multiple measures of financial constraints confirm that the weaker stock price response to monetary policy in firms with more intangible assets is more pronounced among financially constrained firms, consistent with the credit channel predictions.

\subsubsection{Investment Response}

We now assess whether also the weaker investment response to monetary policy in firms with more intangible assets is more pronounced among financially constrained firms. To examine this, we re-run the investment local projection regressions from Table 3, while splitting the sample based on the measures of financial constraints. All regressions include the same control variables, interactions, and fixed effects as the baseline local projections in Table 3.

Table 5 documents the investment response to monetary policy at 8 and 12 quarter horizons, for the splits based on different measures of financial constraints: age (panel A), cash holdings (panel B), and the textual analysis-based delaycon measure (panel C). The results consistently reveal that the coefficient estimates on the interaction of the intangible ratio with the instrumented 1-year Treasury rate are at least

\footnotetext{
${ }^{13}$ We pool the two lower cash holding terciles because the relation between cash and financial constraints is not as monotonic as that between age and financial constraints. While high cash holdings indicate precautionary hoarding, median cash holdings are unlikely indicative of tighter constraints compared to low cash holdings. In fact, very low cash holdings may stem from poor firm performance, which tightens financial constraints.

${ }^{14}$ The sample size is smaller because the delaycon measure is available only over 1997-2015 and only for firms with a machinereadable capitalization and liquidity section of their financial report. Defining financially constrained firms as those in the top tercile of the delaycon measure yields even larger coefficient estimates for these firms.
} 
twice as high for constrained firms than for unconstrained firms. Coefficient estimates for unconstrained firms furthermore have lower or no statistical significance. These results confirm that, consistent with the stock price reaction, also the weaker investment response to monetary policy in firms with more intangible assets is more pronounced among financially constrained firms. ${ }^{15}$

We now proceed to analyze what these results imply for the monetary policy response of tangible versus intangible investment. Note the credit channel offers no direct prediction as to how an individual firm would adjust its tangible-to-intangible investment mix depending on the intensity of financial constraints. Moreover, the tangible-to-intangible investment mix within a firm may be constrained by the production function. For example, in the extreme case of a Leontieff production function, a firm would always adjust tangible and intangible investment proportionately, independently of financial constraints. Still, our finding that the response of total investment to monetary policy is weaker in firms with more intangible assets, especially among financially constrained firms (Table 5), has implications for the tangible-to-intangible investment mix in the aggregate. To see this, note that firms with more tangible assets make more of tangible investment, while firms with more intangible assets make more of intangible investment (the average ratio of tangible over intangible investment is 0.43 among intangible firms and 4.65 among tangible firms, see Table 1).Since firms with more intangible assets adjust their total investment less in response to monetary policy, aggregate intangible investment should also react less to monetary policy, especially among financially constrained firms.

To test for this effect, we aggregate firm-level tangible and intangible investment across the subsets of firms that are more and less credit constrained, as captured by age, cash holdings, and delaycon measures of financial constraints. Figure 7 documents the impulse response of the difference in the tangible and intangible investment growth (similar to panel D of Figure 4), distinguishing between financially constrained and unconstrained firms.

Panel A plots the difference in the response of tangible and intangible investment growth for young and old firms. Among old firms, this difference reaches 3\% after 10 quarters. By contrast, among young firms,

\footnotetext{
${ }^{15}$ It is interesting to relate these results to Caggese and Pérez-Orive (2020) (hereafter CP). CP argue that accommodative monetary policy reduces income on corporate savings, disadvantaging firms with intangible capital. Similar to us, they expect these effects to be more pronounced in constrained firms that rely more on accumulated earnings. Yet, the respective empirical results are very distinct. First, in $\mathrm{CP}$, monetary policy affects investment with long lags of 18 quarters and peak effects at close to 30 quarters (CP, Figure 14). By contrast, we document the effects of monetary policy on firm investment at standard monetary policy horizons of 8-12 quarters (as in, e.g., Gertler and Karadi, 2015). Second, local projections in CP point to an accommodative effect of monetary tightening for young firms with intangible assets and for all old firms. By contrast, we document that the effect of monetary tightening on firm investment is always contractionary-even when attenuated by intangible assets - as consistent with common priors. We verify these results using multiple measures of financial constraints, and establish their counterparts in the analysis of firm stock price response to monetary policy.
} 
this difference exceeds $6 \%$ after 12 quarters, and reaches almost $8 \%$ after 15 quarters. Panel B plots the difference-in-difference, and documents that it reaches 3-5\% and is statistically significant throughout.

Panels C and D replicate these results for cash holdings as a measure of financial constraints, and panels E and $\mathrm{F}$ for the textual analysis-based delaycon measure. The results are consistent across the three measures. Tangible investment reacts more to monetary policy, and this effect is about twice as strong among financially constrained firms.

\subsubsection{Borrowing Response}

While we use credit channel predictions to analyze firm investment, the credit channel is fundamentally a liability side mechanism. The credit channel presupposes that firms with more intangible assets adjust their borrowing less in response to monetary policy, because they are less exposed to changes in collateral-based credit constraints. To confirm this, we extend our analysis by documenting how firms adjust their borrowing in response to monetary policy. ${ }^{16}$

Figure 6 documents that firms with more intangible capital indeed reduce their debt growth less in response to monetary policy, consistent with the credit channel mechanism. Debt growth declines by 0.35 percentage points after 10 quarters on the full sample (compared to a mean debt growth of $2.9 \%$ ), but by a smaller 0.2 percentage points for intangible firms and a larger 0.5 percentage points for tangible firms.

Table 6 captures the effect of intangible assets on debt growth with an interaction term in the local projection regressions. We further compare the coefficient estimates on the interaction of the intangible ratio with the instrumented 1-year Treasury rate across the sample splits by firm financial constraints (analogous to the investment analysis in Table 5). The coefficient estimates are larger among young firms (panel A), and among firms with an above-median delaycon measure (panel B). Thus, the effect where firms with more intangible assets adjust their borrowing less in response to monetary policy is more pronounced among credit constrained firms, again consistent with the credit channel mechanism. ${ }^{17}$

\footnotetext{
${ }^{16}$ We capture the adjustment of firm borrowing as the change in the log sum of short term debt and long term debt (Compustat items $D L C$ and $D L T T$ ).

${ }^{17}$ We do not report the results for cash, because cash affects the need for external financing (and adjustments to debt) directly and not only as a proxy for firm financial constraints.
} 


\subsection{Depreciation Rates}

Intangible assets depreciate faster than tangible assets. The BEA estimates R\&D capital depreciation rates to be $10-40 \%$ depending on the industry ( $\mathrm{Li}, 2012)$, and Ewens et al. (2019) estimate an average R\&D capital depreciation rate of $32 \%$ based on the analysis of capital acquisition prices. This contrasts with an average tangible capital depreciation rate of under $10 \%$ in the BEA data. ${ }^{18}$

Crouzet and Eberly (2019) argue that a higher depreciation rate of intangible assets makes their user cost of capital less interest rate sensitive. To see this, consider a standard neoclassical production model. Firms scale investment up until the marginal product of capital equals its user cost, which is comprised of the interest rate $r$ and the depreciation rate $\delta: F^{\prime}\left(K_{t}\right)=r_{t}+\delta$. Denote the marginal product of capital $f\left(K_{t}\right)=F^{\prime}\left(K_{t}\right)$, and assume that $f$ is decreasing and convex: $f^{\prime}\left(K_{t}\right)<0$ and $f^{\prime \prime}\left(K_{t}\right)>0$. Then, the inverse of $f$ is also decreasing and convex. Under these conditions, investment $I_{t}=K_{t}-K_{t-1}$ is decreasing in the interest rate: $\partial I_{t} / \partial r_{t}=\partial K_{t} / \partial r_{t}=\left(f^{-1}\right)^{\prime}\left(r_{t}+\delta\right)<0$, but less so for a higher depreciation rate: $\partial^{2} I_{t} / \partial r_{t} \partial \delta=\left(f^{-1}\right)^{\prime \prime}\left(r_{t}+\delta\right)>0$. The assumption of decreasing and convex marginal product of capital holds for a number of standard production functions, such as Cobb-Douglas.

Furthermore, consider the decomposition of firm investment into its tangible and intangible components: $I_{t}=\mu I_{t}^{I N T}+(1-\mu) I_{t}^{T A N}$, with the respective depreciation rates $\delta^{I N T}>\delta^{T A N}$. Then, the share of intangible investment $\mu$ affects the response of total investment to monetary policy more when the depreciation gap between $\delta^{I N T}$ and $\delta^{T A N}$ is larger: $\partial^{2} I_{t} / \partial r_{t} \partial \mu=\partial^{2} I_{t} / \partial r_{t} \partial \delta \times \partial \delta / \partial \mu=\partial^{2} I_{t} / \partial r_{t} \partial \delta \times\left(\delta^{I N T}-\delta^{T A N}\right)$. See Figure A3 for a visual illustration of the depreciation channel.

The depreciation channel, if present, predicts that the effect where firms with more intangible assets respond less to monetary policy is more pronounced among firms with a higher difference between tangible and intangible asset depreciation rates. To test this prediction, we calculate for each firm the difference between intangible and tangible capital depreciation rates, which we call a firm's "depreciation gap". We use depreciation rates on tangible assets at industry level from the BEA Fixed Assets Tables 3.3 and 3.6, and depreciation rates on intangible assets - knowledge (R\&D) capital and organizational (SG\&A) capital—from Ewens et al. (2019). The resulting depreciation gap measure varies from $6 \%$ to $40 \%$, with a mean and median around $22 \%$ (see the summary statistics in Table 1).

Table 7 documents firm stock price and total investment response to monetary policy, while splitting the sample into firms with above- and below-median depreciation gap in a given quarter. Panel A estimates stock

\footnotetext{
${ }^{18}$ BEA Fixed Asset Tables 3.3 and 3.6.
} 
price response to monetary policy (as in Table 2) on the respective subsample. The coefficient estimates for the interaction term between $\Delta \mathrm{FF} 4$ and the firm's intangible ratio are up to twice as large for firms with a high depreciation gap than for firms with a low depreciation gap. Panel B estimates total investment response to monetary policy (as in Table 3) at 8 and 12 quarters on the subsamples. The coefficient estimates for the interaction between the instrumented 1-year Treasury rate and the firm's intangible ratio are twice as high for firms with a high depreciation gap. The results confirm that the weaker response to monetary policy in firms with more intangible assets is more pronounced if the difference between the depreciation rate of intangible and tangible assets is higher, consistent with the depreciation channel predictions.

Figure 8 documents the effects of the depreciation channel on the aggregate dynamics of tangible and intangible investment (estimated in the same way as in Figure 6 for the credit channel). Panel A reports the difference in the response of tangible and intangible aggregate investment to a 25bp monetary policy shock, in the sub-samples of firms with high and low depreciation gaps. It shows that the weaker response of intangible investment to monetary policy is more pronounced among firms with a high gap between tangible and intangible asset depreciation rates. Panel B plots the difference-in-difference of the tangible and intangible investment response across the two subsamples, and documents that this difference is statistically significant with $95 \%$ confidence after about 11 quarters.

Overall, our results are thus consistent with the depreciation channel contributing to the weaker stock price and total investment response to monetary policy in firms with more intangible assets, and to a weaker intangible investment response to monetary policy.

\subsection{Adjustment Costs}

Another potential reason for a weaker response of intangible investment to monetary policy is higher investment adjustment costs. Creating tangible and intangible assets takes planning and production time. This makes investment a forward-looking, not easily reversible, multi-period decision. The literature identifies a number of features of intangible investment that contribute to its higher adjustment costs.

First, compared to tangible assets, intangible assets more often have to be built rather than purchased. The reason is that intangible assets are firm-specific and therefore not easily redeployable (Bates et al., 2009; Falato et al., 2018). ${ }^{19}$ Consequently, creating intangible assets takes more time. Related, also downsizing

\footnotetext{
${ }^{19}$ Dell'Ariccia et al. (2020) document that, while patents make intangible assets more redeployable, even patented intangible assets appear less redeployable than tangible assets.
} 
intangible assets is costlier, as they have to be liquidated rather than sold. This makes intangible investment more irreversible.

Second, it is harder to scale intangible investment up and down. The creation of intangible assets hinges on highly skilled human capital as a key production factor (Döttling et al., 2020), and hiring and firing scarce talent is difficult and costly. Indeed, Eisfeldt and Papanikolaou (2013) document that firms with more organizational capital are more likely to list the loss of talent as a risk in their annual reports. Related, Roberts and Weitzman (1981) argue that R\&D projects often require sequential and irreversible investment outlays, pointing to both high adjustment costs and a long time to build. Overall, Peters and Taylor (2017) document that "compared with physical capital, intangible capital adjusts more slowly to changes in investment opportunities."

Interestingly, the effect of adjustment costs on investment response to monetary policy is ex ante ambiguous. On the one hand, mechanically, investment with high adjustment costs may respond less to monetary policy, especially over shorter time horizons. On the other hand, the literature documents that investment with high adjustment costs responds negatively to uncertainty (Majd and Pindyck, 1985; Bloom, 2009). The reason is that such investment is more irreversible, and uncertainty increases the risk that the investment will not pay off in the future. At the same time, uncertainty responds positively to interest rate shocks (Bekaert et al., 2013). ${ }^{20}$ That is, accommodative monetary policy reduces uncertainty, which fosters investment with high adjustment costs, while restrictive monetary policy increases uncertainty, which dampens such investment. Due to this uncertainty effect, investment with high adjustment costs may respond more to monetary policy.

Analyzing the effects of investment adjustment costs is constrained by data availability. Ideally, we would use firm-level data on tangible and intangible investment adjustment costs. This would allow us to compute a firm's "adjustment costs gap" (the difference between adjustment costs of tangible and intangible investment, akin to the "depreciation gap" of the previous subsection) and consider how it affects the relative response of tangible and intangible firms to monetary policy. Alas, the existing Kim and Kung (2017) firm-level estimates of asset redeployability and Hall (2004) industry-level measures of investment adjustment costs focus on tangible assets only. ${ }^{21}$ Thus we cannot test directly whether adjustment costs contribute to the

\footnotetext{
${ }^{20}$ In our data, the correlation between interest rate shocks and VIX is 0.12 and significant at the $0.1 \%$ level.

${ }^{21}$ The correlation between the measures of investment adjustment costs and of firm financial constraints is generally low (see Table A4). Redeployability is negatively correlated with depreciation gaps, due to a positive correlation between redeployability and tangible asset deprecation rates. This is consistent with firms preferring to buy rather than build assets that become obsolete fast. Kim and Kung (2017) asset redeployability and Hall (2004) adjustment costs have a low negative correlation, suggesting that they capture different dimensions of investment adjustment costs.
} 
weaker response of intangible investment to monetary policy. However, we can shed light on the impact of adjustment costs indirectly, by establishing their effect on the response of tangible investment to monetary policy, and extrapolating this effect to the comparison between tangible and intangible investment.

Figure 9 uses sample splits to document that more inert tangible investment - that with below-median asset redeployability (panel A) or above-median investment adjustment costs (panel B) - responds, if anything, more to monetary policy. This is consistent with the effect of monetary policy on investment with high adjustment costs that operates through the impact of monetary policy on uncertainty. ${ }^{22}$ Extrapolating this finding to a comparison between tangible and more inert intangible investment would suggest that intangible investment should respond more to monetary policy. Thus, this indirect test cannot support the notion that higher adjustment costs contribute to the weaker response of intangible investment to monetary policy.

\section{Conclusion}

Technological progress and the transition to a service economy increase the importance of corporate intangible assets. This paper sheds light on how this transition affects the effectiveness of monetary policy. The key result is that monetary policy impacts investment less when more of corporate investment is intangible. The stock prices and investment of firms with more intangible assets react less to monetary policy, and intangible investment reacts less to monetary policy compared to tangible investment. In the cross-section, these attenuating effects of intangible assets is most pronounced among credit constrained firms and firms with a large difference between tangible and intangible asset depreciation rates.

These findings have important economic policy implications. The rise of corporate intangible capital makes corporate investment less responsive to monetary policy, and technological progress is likely to keep eroding the investment channel of monetary policy in the future. This trend sheds additional light on why investment has been relatively weak during the past decades, despite aggressive monetary easing (Summers, 2015; Gutiérrez and Philippon, 2017). Given these frictions in the transmission of monetary policy, intangible investment may best be encouraged by other than monetary means (e.g. fiscal), and by encouraging equity rather than debt financing of firms.

\footnotetext{
${ }^{22}$ The result that less redeployable investment responds more to monetary policy is consistent with the Kim and Kung (2017) finding that firms with less redeployable assets respond more to uncertainty shocks. This result also suggests that the adjustment costs channel dominates any effects where firms with more redeployable assets use more collateral (Benmelech and Bergman, 2009) and are more exposed to monetary policy through the credit channel. This is again consistent with the Kim and Kung (2017) finding that the effects of uncertainty on firms with more redeployable assets are invariant in firm financial constraints: more use of collateral in firms with more redeployable assets is offset by more stable market prices of more redeployable collateral.
} 
Table 1: Summary Statistics of Compustat Variables

Summary statistics are reported for all firms, and for intangible and tangible firms separately. Intangible firms are defined as those with an above-median intangible ratio (intangible-to-total asset ratio) in a given quarter. Tangible firms are below the median. The sample runs from 1991-2016 and includes all firms in the matched CRSP-Compustat sample excluding financial firms, utilities and government. Variable definitions are in Table A1.

\begin{tabular}{|c|c|c|c|c|c|c|c|c|c|}
\hline & \multicolumn{3}{|c|}{ All } & \multicolumn{3}{|c|}{ Intangible Firms } & \multicolumn{3}{|c|}{ Tangible Firms } \\
\hline & mean & p50 & sd & mean & p50 & sd & mean & $\mathrm{p} 50$ & $\mathrm{sd}$ \\
\hline Intangible Ratio & 0.580 & 0.657 & 0.289 & 0.815 & 0.824 & 0.0972 & 0.345 & 0.354 & 0.218 \\
\hline Total Q (PT) & 1.676 & 1.396 & 0.899 & 1.765 & 1.463 & 0.953 & 1.581 & 1.333 & 0.826 \\
\hline Cash & 0.129 & 0.0596 & 0.162 & 0.168 & 0.0908 & 0.186 & 0.0940 & 0.0458 & 0.121 \\
\hline Leverage & 0.287 & 0.247 & 0.251 & 0.230 & 0.188 & 0.226 & 0.310 & 0.281 & 0.239 \\
\hline Age & 63.87 & 50 & 48.18 & 68.37 & 55 & 48.14 & 66.31 & 52 & 49.39 \\
\hline Book Assets & 1.925 & 0.287 & 8.273 & 1.734 & 0.298 & 6.231 & 2.362 & 0.321 & 10.67 \\
\hline Total Assets & 2.360 & 0.405 & 9.886 & 2.454 & 0.475 & 8.671 & 2.626 & 0.388 & 12.08 \\
\hline Cashflows & 0.0311 & 0.0322 & 0.0366 & 0.0298 & 0.0314 & 0.0378 & 0.0343 & 0.0341 & 0.0338 \\
\hline Dividend Paid & 0.433 & 0 & 0.496 & 0.400 & 0 & 0.490 & 0.482 & 0 & 0.500 \\
\hline Debt Growth & 0.0289 & -0.00861 & 0.361 & 0.0214 & -0.0108 & 0.392 & 0.0383 & -0.00719 & 0.341 \\
\hline Delaycon & -0.0152 & -0.0216 & 0.0884 & -0.0205 & -0.0273 & 0.0888 & -0.0117 & -0.0172 & 0.0871 \\
\hline Depreciation Gap & 0.223 & 0.236 & 0.0565 & 0.224 & 0.234 & 0.0593 & 0.223 & 0.236 & 0.0527 \\
\hline Total Inv. Rate & 0.0548 & 0.0448 & 0.0401 & 0.0549 & 0.0468 & 0.0357 & 0.0550 & 0.0424 & 0.0442 \\
\hline Tangible Inv. Rate & 0.0663 & 0.0463 & 0.0663 & 0.0761 & 0.0562 & 0.0672 & 0.0580 & 0.0394 & 0.0623 \\
\hline Intan Inv. Rate & 0.0552 & 0.0475 & 0.0375 & 0.0523 & 0.0456 & 0.0346 & 0.0582 & 0.0499 & 0.0399 \\
\hline CAPX / Intan Inv. & 2.424 & 0.509 & 6.152 & 0.426 & 0.259 & 0.846 & 4.652 & 1.483 & 8.402 \\
\hline CAPX / R\&D & 1.733 & 0.546 & 3.968 & 0.790 & 0.388 & 1.746 & 4.243 & 1.857 & 6.339 \\
\hline Observations & 318305 & & & 137863 & & & 137915 & & \\
\hline
\end{tabular}


Table 2: Stock Returns Around FOMC Meetings

The dependent variable is a firm's stock returns on an FOMC announcement day. Columns 1-3 consider raw returns, and columns 4 and 5 consider abnormal returns, with betas estimated over a 100-day window before the event date using CRSP value-weighted index as market benchmark. $\triangle \mathrm{FF} 4$ is the change in the 3-months ahead Fed Funds futures rate in the 30 minutes around the FOMC announcement. Intangible Ratio is the firm's intangible-to-total asset ratio. Other control variables are defined in Table A1. The sample includes all FOMC meetings over 1991-2016, except the meeting on September 17, 2001, and covers all firms in the matched CRSP-Compustat sample excluding financial firms, utilities and government. Industry fixed effects are based on 4-digit NAICS codes. Standard errors in parenthesis are clustered by event date and industry. ***, **,* indicate significance levels of $1 \%, 5 \%$, and $10 \%$, respectively.

\begin{tabular}{|c|c|c|c|c|c|}
\hline & $\begin{array}{c}(1) \\
\text { Raw Return } \\
\end{array}$ & $\begin{array}{c}(2) \\
\text { Raw Return } \\
\end{array}$ & $\begin{array}{c}(3) \\
\text { Raw Return } \\
\end{array}$ & $\begin{array}{c}(4) \\
\text { Abnormal Return } \\
\end{array}$ & $\begin{array}{c}(5) \\
\text { Abnormal Return }\end{array}$ \\
\hline$\Delta \mathrm{FF} 4$ & $\begin{array}{c}-4.36^{* *} \\
(1.76)\end{array}$ & & & & \\
\hline$\Delta \mathrm{FF} 4 \times$ Intangible Ratio & & $\begin{array}{l}1.53^{* *} \\
(0.67)\end{array}$ & $\begin{array}{l}1.45^{* *} \\
(0.70)\end{array}$ & $\begin{array}{l}1.56^{* *} \\
(0.64)\end{array}$ & $\begin{array}{c}1.42^{* *} \\
(0.67)\end{array}$ \\
\hline$\Delta \mathrm{FF} 4 \times \log$ Age & & $\begin{array}{l}0.62^{* *} \\
(0.24)\end{array}$ & $\begin{array}{c}0.65^{* * *} \\
(0.24)\end{array}$ & $\begin{array}{l}0.076 \\
(0.27)\end{array}$ & $\begin{array}{l}0.090 \\
(0.27)\end{array}$ \\
\hline$\Delta \mathrm{FF} 4 \times$ Total $\mathrm{Q}$ & & $\begin{array}{l}-0.37 \\
(0.49)\end{array}$ & $\begin{array}{l}-0.41 \\
(0.49)\end{array}$ & $\begin{array}{c}0.15 \\
(0.31)\end{array}$ & $\begin{array}{c}0.13 \\
(0.31)\end{array}$ \\
\hline$\Delta \mathrm{FF} 4 \times$ Cash & & $\begin{array}{l}-3.78^{*} \\
(2.28)\end{array}$ & $\begin{array}{l}-3.90^{*} \\
(2.20)\end{array}$ & $\begin{array}{l}-0.11 \\
(1.03)\end{array}$ & $\begin{array}{l}-0.12 \\
(1.00)\end{array}$ \\
\hline$\Delta \mathrm{FF} 4 \times$ Leverage & & $\begin{array}{l}-0.33 \\
(0.96)\end{array}$ & $\begin{array}{l}-0.34 \\
(0.95)\end{array}$ & $\begin{array}{l}-1.08 \\
(0.88)\end{array}$ & $\begin{array}{l}-1.13 \\
(0.88)\end{array}$ \\
\hline$\Delta \mathrm{FF} 4 \times$ Cashflows & & $\begin{array}{l}-1.93 \\
(6.42)\end{array}$ & $\begin{array}{l}-1.17 \\
(6.89)\end{array}$ & $\begin{array}{r}-7.51^{*} \\
(4.26)\end{array}$ & $\begin{array}{l}-7.33 \\
(4.50)\end{array}$ \\
\hline$\Delta$ FF $4 \times$ Log Size & & $\begin{array}{c}-0.59^{* *} \\
(0.28)\end{array}$ & $\begin{array}{c}-0.61^{* *} \\
(0.27)\end{array}$ & $\begin{array}{r}-0.027 \\
(0.11)\end{array}$ & $\begin{array}{r}-0.027 \\
(0.12)\end{array}$ \\
\hline$\Delta \mathrm{FF} 4 \times$ Dividend Paid & & $\begin{array}{c}0.43 \\
(0.37) \\
\end{array}$ & $\begin{array}{c}0.38 \\
(0.38) \\
\end{array}$ & $\begin{array}{l}-0.23 \\
(0.21) \\
\end{array}$ & $\begin{array}{l}-0.27 \\
(0.22)\end{array}$ \\
\hline Observations & 435218 & 426442 & 426391 & 426442 & 426391 \\
\hline R-squared & 0.030 & 0.243 & 0.263 & 0.143 & 0.164 \\
\hline Industry $\times$ Event-Date FE & No & Yes & Yes & Yes & Yes \\
\hline Firm FE & Yes & No & Yes & No & Yes \\
\hline Fiscal Quarter FE & Yes & Yes & Yes & Yes & Yes \\
\hline Firm-Level Controls & Yes & Yes & Yes & Yes & Yes \\
\hline
\end{tabular}


Table 3: Investment Response

The dependent variable is the $h$-quarter change in the log total investment rate. $R$ is the 1-year Treasury rate, instrumented by cumulative high-frequency shocks, each measured as a change in the 3-month ahead Fed Funds futures rate in the 30 minutes window around FOMC announcements. Intangible Ratio is the firm's intangible-to-total asset ratio. Other control variables are defined in Table A1. The sample includes all FOMC meetings over 1991-2016, except the meeting on September 17, 2001, and covers all firms in the matched CRSP-Compustat sample excluding financial firms, utilities and government. In parentheses we report Driscoll-Kraay heteroscedasticity and autocorrelation robust standard errors standard errors. $* * *, * *, *$ indicate significance levels of $1 \%, 5 \%$, and $10 \%$, respectively. Non-interacted coefficients are omitted for brevity.

\begin{tabular}{|c|c|c|c|c|c|c|}
\hline & \multicolumn{3}{|c|}{$h=8$} & \multicolumn{3}{|c|}{$h=12$} \\
\hline & $\begin{array}{c}(1) \\
\Delta I_{t}^{t o t}\end{array}$ & $\begin{array}{c}(2) \\
\Delta I_{t}^{t o t} \\
\end{array}$ & $\begin{array}{c}(3) \\
\Delta I_{t}^{t o t}\end{array}$ & $\begin{array}{c}(4) \\
\Delta I_{t}^{t o t}\end{array}$ & $\begin{array}{c}(5) \\
\Delta I_{t}^{t o t} \\
\end{array}$ & $\begin{array}{c}(6) \\
\Delta I_{t}^{t o t}\end{array}$ \\
\hline $\mathrm{R}$ & $\begin{array}{c}-0.080 * * * \\
(0.015)\end{array}$ & $\begin{array}{c}-0.11^{* *} \\
(0.046)\end{array}$ & & $\begin{array}{c}-0.088^{* * *} \\
(0.016)\end{array}$ & $\begin{array}{c}-0.11^{* *} \\
(0.048)\end{array}$ & \\
\hline $\mathrm{R} \times$ Intangible Ratio & & $\begin{array}{c}0.039^{* *} \\
(0.020)\end{array}$ & $\begin{array}{l}0.037^{*} \\
(0.020)\end{array}$ & & $\begin{array}{c}0.051^{* *} \\
(0.023)\end{array}$ & $\begin{array}{c}0.049^{* *} \\
(0.023)\end{array}$ \\
\hline $\mathrm{R} \times \log$ Age & & $\begin{array}{c}0.0092 \\
(0.0092)\end{array}$ & $\begin{array}{c}0.0067 \\
(0.0062)\end{array}$ & & $\begin{array}{c}0.0028 \\
(0.0089)\end{array}$ & $\begin{array}{c}0.0060 \\
(0.0058)\end{array}$ \\
\hline $\mathrm{R} \times$ Total $\mathrm{Q}$ & & $\begin{array}{c}-0.0093^{* *} \\
(0.0043)\end{array}$ & $\begin{array}{c}-0.012^{* * *} \\
(0.0038)\end{array}$ & & $\begin{array}{c}-0.0100^{* *} \\
(0.0048)\end{array}$ & $\begin{array}{c}-0.0090^{* *} \\
(0.0042)\end{array}$ \\
\hline $\mathrm{R} \times \mathrm{Cash}$ & & $\begin{array}{c}0.013 \\
(0.012)\end{array}$ & $\begin{array}{c}0.025 * * \\
(0.011)\end{array}$ & & $\begin{array}{c}0.032^{* * *} \\
(0.012)\end{array}$ & $\begin{array}{c}0.040 * * * \\
(0.012)\end{array}$ \\
\hline $\mathrm{R} \times$ Leverage & & $\begin{array}{l}0.0099^{*} \\
(0.0055)\end{array}$ & $\begin{array}{c}0.0052 \\
(0.0054)\end{array}$ & & $\begin{array}{c}0.0059 \\
(0.0097)\end{array}$ & $\begin{array}{c}0.0036 \\
(0.0094)\end{array}$ \\
\hline $\mathrm{R} \times$ Size & & $\begin{array}{c}-0.0022^{*} \\
(0.0011)\end{array}$ & $\begin{array}{c}-0.0020^{*} \\
(0.0010)\end{array}$ & & $\begin{array}{l}-0.0013 \\
(0.0017)\end{array}$ & $\begin{array}{l}-0.0010 \\
(0.0015)\end{array}$ \\
\hline $\mathrm{R} \times$ Cashflows & & $\begin{array}{c}0.039 \\
(0.051)\end{array}$ & $\begin{array}{c}0.038 \\
(0.051)\end{array}$ & & $\begin{array}{c}0.070 \\
(0.075)\end{array}$ & $\begin{array}{c}0.049 \\
(0.076)\end{array}$ \\
\hline $\mathrm{R} \times$ Dividend Paid & & $\begin{array}{c}0.0048 \\
(0.0038) \\
\end{array}$ & $\begin{array}{c}0.0054 \\
(0.0032) \\
\end{array}$ & & $\begin{array}{c}0.0046 \\
(0.0040) \\
\end{array}$ & $\begin{array}{c}0.0022 \\
(0.0036) \\
\end{array}$ \\
\hline Observations & 159027 & 159027 & 159027 & 141590 & 141590 & 141590 \\
\hline R-squared & 0.071 & 0.073 & 0.053 & 0.101 & 0.105 & 0.075 \\
\hline Firm FE & Yes & Yes & Yes & Yes & Yes & Yes \\
\hline Fiscal Quarter FE & Yes & Yes & Yes & Yes & Yes & Yes \\
\hline Firm-Level Controls & Yes & Yes & Yes & Yes & Yes & Yes \\
\hline Macro Controls & Yes & Yes & No & Yes & Yes & No \\
\hline Time FE & No & No & Yes & No & No & Yes \\
\hline
\end{tabular}


Table 4: Stock Returns Around FOMC Meetings - Sample Splits Credit Channel

This table replicates the stock returns regressions from Table 2 for different sub-samples of firms. In panel A, young (old) firms are those in the lowest (highest) tercile of the age distribution in a given quarter (see Table A5 for the middle tercile). In panel $\mathrm{B}$, high cash firms are those in the top tercile of the cash-to-asset ratio distribution in a given quarter, and low cash are those in the bottom two terciles. In panel C, more (less) constrained firms have an above-median (below-median) textual analysis-based delaycon financial constraints measure of Hoberg and Maksimovic (2015). The dependent variables are raw or abnormal stock returns on FOMC announcement days. Abnormal returns betas are estimated over a 100-day window before the event date, using CRSP value-weighted index as market benchmark. $\triangle \mathrm{FF} 4$ is the change in the 3-month ahead Fed Futures rate in the 30 minutes around the FOMC announcement. Intangible Ratio is the firm's intangible-to-total asset ratio. Other control variables are defined in Table A1. The sample includes all FOMC meetings over 1991-2016, except the meeting on September 17, 2001, and covers all firms in the matched CRSP-Compustat sample excluding financial firms, utilities and government. All regressions include firm fixed effects, fiscal quarter fixed effects, and industry $\times$ event-date fixed effects based on 4-digit NAICS codes, as well as the same control variables and interaction terms as in the baseline regression (Table 2). Standard errors in parentheses are clustered by event date and industry. $* * *, * *, *, \S$, indicate significance levels of $1 \%, 5 \%, 10 \%$, and $15 \%$, respectively.

\begin{tabular}{|c|c|c|c|c|}
\hline & $\begin{array}{c}(1) \\
\text { Raw Return }\end{array}$ & $\begin{array}{c}(2) \\
\text { Abnormal Return }\end{array}$ & $\begin{array}{c}(3) \\
\text { Raw Return }\end{array}$ & $\begin{array}{c}(4) \\
\text { Abnormal Return }\end{array}$ \\
\hline \multicolumn{5}{|l|}{ Panel A: Split by Age } \\
\hline & \multicolumn{2}{|c|}{ Young } & \multicolumn{2}{|r|}{ Old } \\
\hline$\Delta \mathrm{FF} 4 \times$ Intangible Ratio & $\begin{array}{c}3.64^{* *} \\
(1.59)\end{array}$ & $\begin{array}{c}3.08^{* *} \\
(1.35)\end{array}$ & $\begin{array}{c}0.75 \\
(1.52)\end{array}$ & $\begin{array}{c}0.25 \\
(1.43)\end{array}$ \\
\hline Observations & 136356 & 136356 & 123172 & 123172 \\
\hline \multicolumn{5}{|c|}{ Panel B: Split by Cash Holdings } \\
\hline & \multicolumn{2}{|c|}{ High Cash } & \multicolumn{2}{|c|}{ Low Cash } \\
\hline$\Delta \mathrm{FF} 4 \times$ Intangible Ratio & $\begin{array}{c}2.78^{* *} \\
(1.13)\end{array}$ & $\begin{array}{c}2.55^{* * *} \\
(0.97)\end{array}$ & $\begin{array}{c}0.47 \\
(1.01)\end{array}$ & $\begin{array}{c}0.66 \\
(1.02)\end{array}$ \\
\hline Observations & 141777 & 141777 & 270370 & 270370 \\
\hline \multicolumn{5}{|c|}{ Panel C: Split by Delaycon } \\
\hline & \multicolumn{2}{|c|}{ More Constrained } & \multicolumn{2}{|c|}{ Less Constrained } \\
\hline$\Delta \mathrm{FF} 4 \times$ Intangible Ratio & $\begin{array}{l}2.25^{\S} \\
(1.51)\end{array}$ & $\begin{array}{c}2.66^{* * *} \\
(0.96)\end{array}$ & $\begin{array}{c}1.51 \\
(1.84)\end{array}$ & $\begin{array}{c}0.31 \\
(1.36)\end{array}$ \\
\hline Observations & 116378 & 116378 & 122967 & 122967 \\
\hline
\end{tabular}


Table 5: Investment Response - Sample Splits Credit Channel

This table replicates the investment regressions from Table 3 on different sub-samples. In panel A, young (old) firms are firms in the lowest (highest) tercile of the age distribution in a given quarter. In panel B, high cash firms are those in the top tercile of the cash-to-asset ratio distribution in a given quarter, and low cash are those in the bottom two terciles. In panel C, more (less) constrained firms have an above-median (below-median) textual analysis-based delaycon financial constraints measure of Hoberg and Maksimovic (2015). The dependent variable is the $h$-quarter change in the log total investment rate. $R$ is the 1 -year Treasury rate, instrumented by cumulative high-frequency shocks, each measured as a change in the 3-month ahead Fed Funds future rate in the 30 minutes window around FOMC announcements. Intangible Ratio is the firm's intangible-to-total asset ratio. Other control variables are defined in Table A1. The sample includes all FOMC meetings over 1991-2016, except the meeting on September 17, 2001, and covers all firms in the matched CRSP-Compustat sample excluding financial firms, utilities and government. All regressions include firm fixed effects, fiscal quarter fixed effects and time fixed effects, as well as the same control variables and interaction terms as in the baseline regressions (Table 3). In parentheses we report Driscoll-Kraay heteroscedasticity and autocorrelation robust standard errors standard errors. ***, **, * indicate significance levels of $1 \%, 5 \%$, and $10 \%$, respectively.

\begin{tabular}{|c|c|c|c|c|}
\hline & $\begin{array}{c}(1) \\
\Delta I_{t}^{t o t} \\
h=8\end{array}$ & $\begin{array}{c}(2) \\
\Delta I_{t}^{t o t} \\
h=12\end{array}$ & $\begin{array}{c}(3) \\
\Delta I_{t}^{t o t} \\
h=8\end{array}$ & $\begin{array}{c}(4) \\
\Delta I_{t}^{t o t} \\
h=12\end{array}$ \\
\hline \multicolumn{5}{|c|}{ Panel A: Split by Age } \\
\hline & \multicolumn{2}{|c|}{ Young } & \multicolumn{2}{|c|}{ Old } \\
\hline$R \times$ Intangible Ratio & $\begin{array}{c}0.098^{* * *} \\
(0.021)\end{array}$ & $\begin{array}{c}0.096^{* * *} \\
(0.024)\end{array}$ & $\begin{array}{c}0.036 \\
(0.022)\end{array}$ & $\begin{array}{l}0.049^{*} \\
(0.027)\end{array}$ \\
\hline Observations & 45569 & 39687 & 58541 & 53183 \\
\hline \multicolumn{5}{|c|}{ Panel B: Split by Cash Holdings } \\
\hline & \multicolumn{2}{|c|}{ High Cash } & \multicolumn{2}{|c|}{ Low Cash } \\
\hline$R \times$ Intangible Ratio & $\begin{array}{c}0.064^{* * *} \\
(0.023)\end{array}$ & $\begin{array}{c}0.067^{* *} \\
(0.031)\end{array}$ & $\begin{array}{c}0.028 \\
(0.020)\end{array}$ & $\begin{array}{c}0.037 \\
(0.022)\end{array}$ \\
\hline Observations & 53136 & 47181 & 105270 & 93839 \\
\hline \multicolumn{5}{|c|}{ Panel C: Split by Delaycon } \\
\hline & \multicolumn{2}{|c|}{ More Constrained } & \multicolumn{2}{|c|}{ Less Constrained } \\
\hline$R \times$ Intangible Ratio & $\begin{array}{c}0.080^{* * *} \\
(0.025)\end{array}$ & $\begin{array}{c}0.076^{* * *} \\
(0.026)\end{array}$ & $\begin{array}{c}0.031 \\
(0.021)\end{array}$ & $\begin{array}{l}0.036^{*} \\
(0.021)\end{array}$ \\
\hline Observations & 48488 & 42951 & 52132 & 46566 \\
\hline
\end{tabular}


Table 6: Debt Growth - Sample Splits Credit Channel

This table presents instrumental-variable local projections for debt growth. The dependent variable is the $h$-quarter change in debt growth, defined as the growth rate of short-term and long-term debt. In panel A, young (old) firms are firms in the lowest (highest) tercile of the age distribution in a given quarter. In panel B, more (less) constrained firms have an above-median (belowmedian) textual analysis-based delaycon financial constraints measure of Hoberg and Maksimovic (2015). $R$ is the 1-year Treasury rate, instrumented by cumulative high-frequency shocks, each measured as a change in the 3-month ahead Fed Funds future rate in the 30 minutes window around FOMC announcements. Intangible Ratio is the firm's intangible-to-total asset ratio. Other control variables are defined in Table A1. The sample includes all FOMC meetings over 1991-2016, except the meeting on September 17, 2001, and covers all firms in the matched CRSP-Compustat sample excluding financial firms, utilities and government. All regressions include firm fixed effects, fiscal quarter fixed effects and time fixed effects, as well as the same control variables and interaction terms as in the baseline investment regressions (Table 3). In parentheses we report Driscoll-Kraay heteroscedasticity and autocorrelation robust standard errors standard errors. ***, **, * indicate significance levels of $1 \%, 5 \%$, and $10 \%$, respectively.

\begin{tabular}{|c|c|c|c|c|}
\hline & $\begin{array}{c}(1) \\
\Delta \text { Debt Growth } \\
h=8\end{array}$ & $\begin{array}{c}(2) \\
\Delta \text { Debt Growth } \\
h=12\end{array}$ & $\begin{array}{c}(3) \\
\Delta \text { Debt Growth } \\
h=8\end{array}$ & $\begin{array}{c}(4) \\
\Delta \text { Debt Growth } \\
h=12\end{array}$ \\
\hline \multicolumn{5}{|c|}{ Panel A: Split by Age } \\
\hline & \multicolumn{2}{|c|}{ Young } & \multicolumn{2}{|c|}{ Old } \\
\hline$R \times$ Intangible Ratio & $\begin{array}{c}0.034^{* * *} \\
(0.0090)\end{array}$ & $\begin{array}{c}0.032^{* * *} \\
(0.0095)\end{array}$ & $\begin{array}{l}0.015^{* *} \\
(0.0074)\end{array}$ & $\begin{array}{c}0.017^{* *} \\
(0.0080)\end{array}$ \\
\hline Observations & 41083 & 35290 & 55909 & 50638 \\
\hline \multicolumn{5}{|c|}{ Panel B: Split by Delaycon } \\
\hline & \multicolumn{2}{|c|}{ More Constrained } & \multicolumn{2}{|c|}{ Less Constrained } \\
\hline$R \times$ Intangible Ratio & $\begin{array}{c}0.026^{* * *} \\
(0.0092)\end{array}$ & $\begin{array}{c}0.024^{* * *} \\
(0.0071)\end{array}$ & $\begin{array}{c}0.021^{* * *} \\
(0.0057)\end{array}$ & $\begin{array}{c}0.014^{* * *} \\
(0.0051)\end{array}$ \\
\hline
\end{tabular}


Table 7: Sample Splits by Depreciation Gap

This table replicates the baseline results for firms with above- and below-median depreciation gap, defined as the difference between a firm's intangible and tangible asset depreciation rates in a given quarter. Panel A replicates the stock returns regressions from Table 2 and the dependent variables are raw or abnormal stock returns on FOMC announcement days. Abnormal returns betas are estimated over a 100-day window before the event date, using CRSP value-weighted index as market benchmark. $\Delta F F 4$ is the change in the 3-month ahead Fed Futures rate in the 30 minutes around the FOMC announcement. Panel B replicates the investment regressions from Table 3 and the dependent variable is the $h$-quarter change in the log total investment rate. $R$ is the 1-year Treasury rate, instrumented by cumulative high-frequency shocks, each measured as a change in the 3-month ahead Fed Funds future rate in the 30 minutes window around FOMC announcements. Intangible Ratio is the firm's intangible-to-total asset ratio. Other control variables are defined in Table A1. The sample includes all FOMC meetings over 1991-2016, except the meeting on September 17, 2001, and covers all firms in the matched CRSP-Compustat sample excluding financial firms, utilities and government. All regressions include the same fixed effects and control variables as in the baseline regressions from Tables 2 and 3, respectively. Standard errors are in parentheses. ${ }^{* *}, * *, *$ indicate significance levels of $1 \%, 5 \%$, and $10 \%$, respectively.

\begin{tabular}{|c|c|c|c|c|}
\hline \multirow[t]{4}{*}{ Panel A: Stock Returns } & \multirow{2}{*}{\multicolumn{2}{|c|}{ High Depreciation Gap }} & \multirow{2}{*}{\multicolumn{2}{|c|}{ Low Depreciation Gap }} \\
\hline & & & & \\
\hline & $(1)$ & $(2)$ & $(3)$ & $(4)$ \\
\hline & Raw Return & Abnormal Return & Raw Return & Abnormal Return \\
\hline$\Delta \mathrm{FF} 4 \times$ Intangible Ratio & $\begin{array}{l}2.20^{*} \\
(1.11)\end{array}$ & $\begin{array}{l}1.90^{*} \\
(1.12)\end{array}$ & $\begin{array}{c}1.18 \\
(1.00)\end{array}$ & $\begin{array}{c}1.38 \\
(0.96)\end{array}$ \\
\hline Observations & 198490 & 198490 & 212553 & 212553 \\
\hline \multirow[t]{2}{*}{ Panel B: Investment } & \multicolumn{2}{|c|}{ High Depreciation Gap } & \multicolumn{2}{|c|}{ Low Depreciation Gap } \\
\hline & $\begin{array}{l}\Delta I_{t}^{t o t} \\
h=8\end{array}$ & $\begin{array}{c}\Delta I_{t}^{t o t} \\
h=12\end{array}$ & $\begin{array}{l}\Delta I_{t}^{t o t} \\
h=8\end{array}$ & $\begin{array}{c}\Delta I_{t}^{t o t} \\
h=12\end{array}$ \\
\hline $\mathrm{R} \times$ Intangible Ratio & $\begin{array}{c}0.054^{* *} \\
(0.025)\end{array}$ & $\begin{array}{c}0.062^{* *} \\
(0.030)\end{array}$ & $\begin{array}{c}0.019 \\
(0.017)\end{array}$ & $\begin{array}{l}0.037^{*} \\
(0.019)\end{array}$ \\
\hline Observations & 75065 & 66224 & 82374 & 74000 \\
\hline
\end{tabular}


Figure 1: Intangible vs Physical Capital and Investment
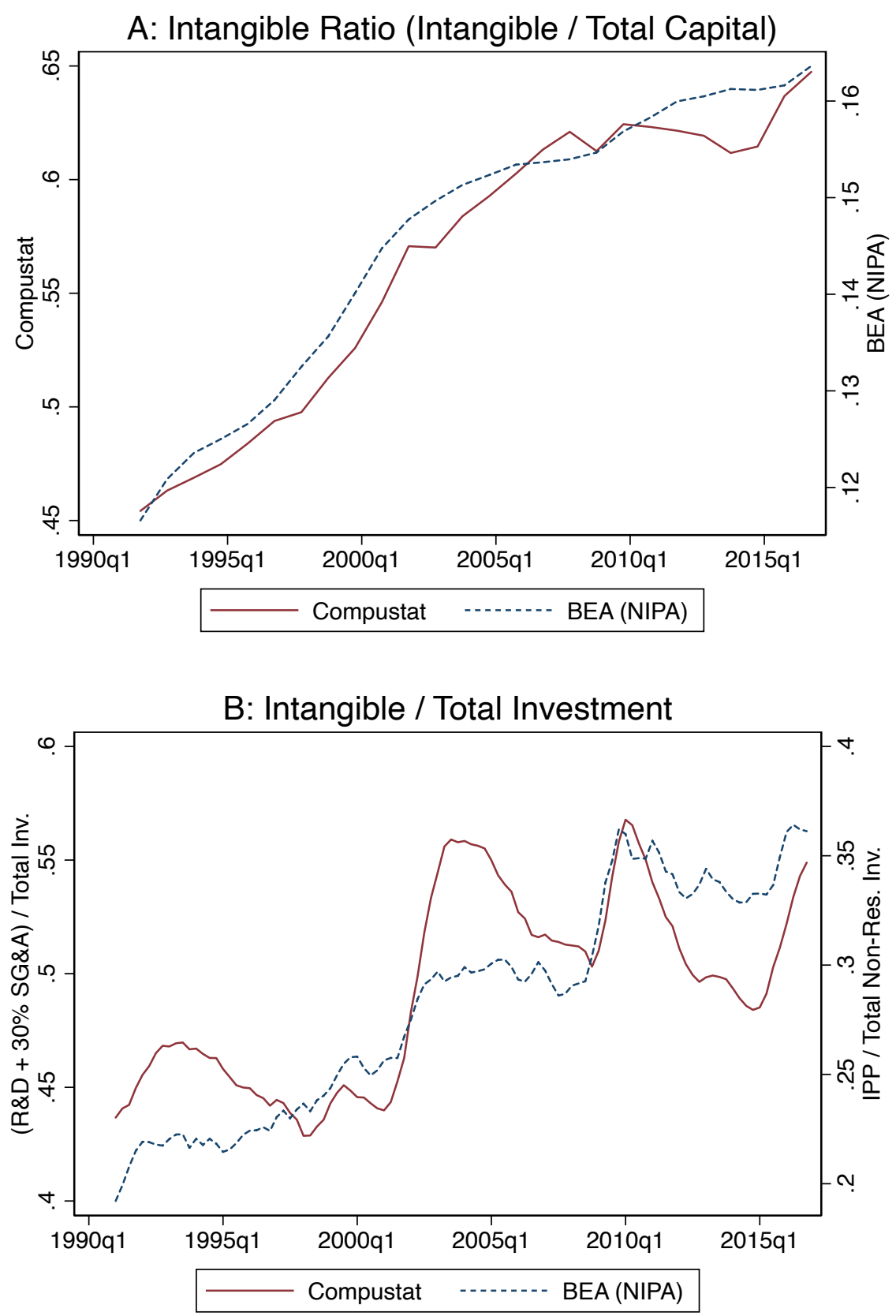
Figure 2: Decomposing Investment Growth
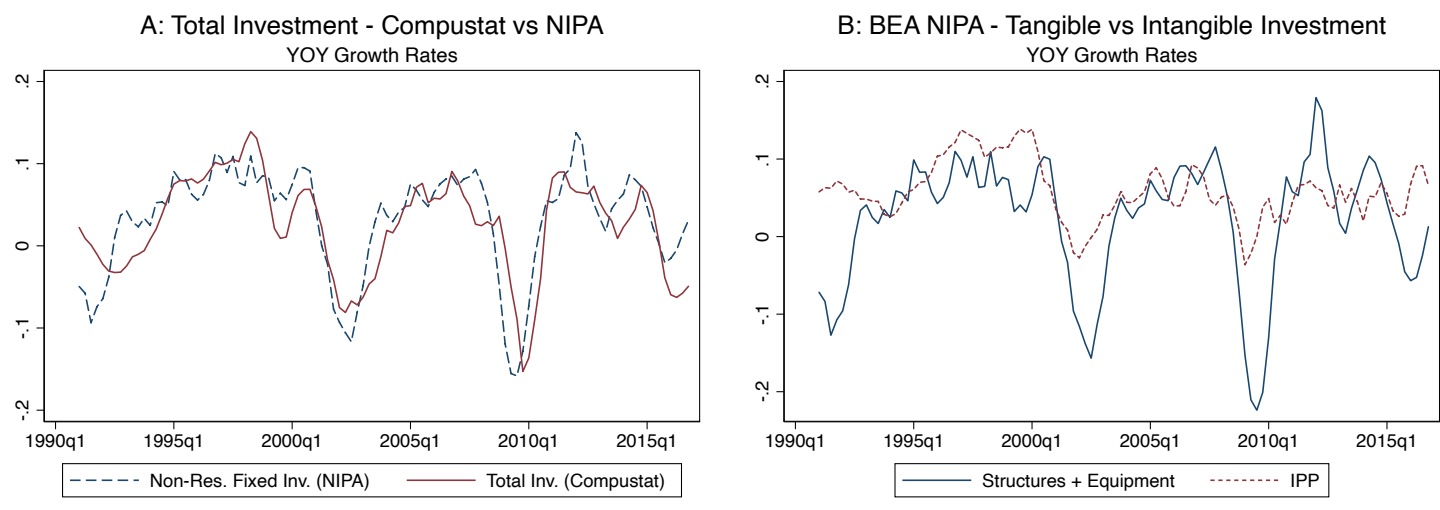

C: Compustat (agg.) - Tangible vs Intangible Investment
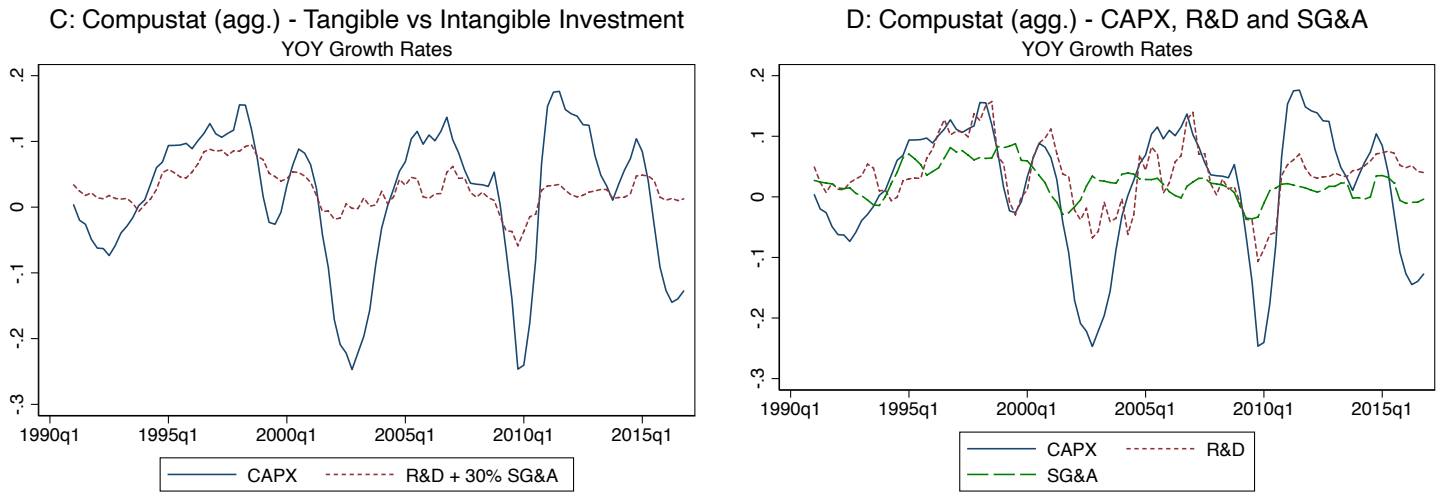
Figure 3: Monetary Policy Measures

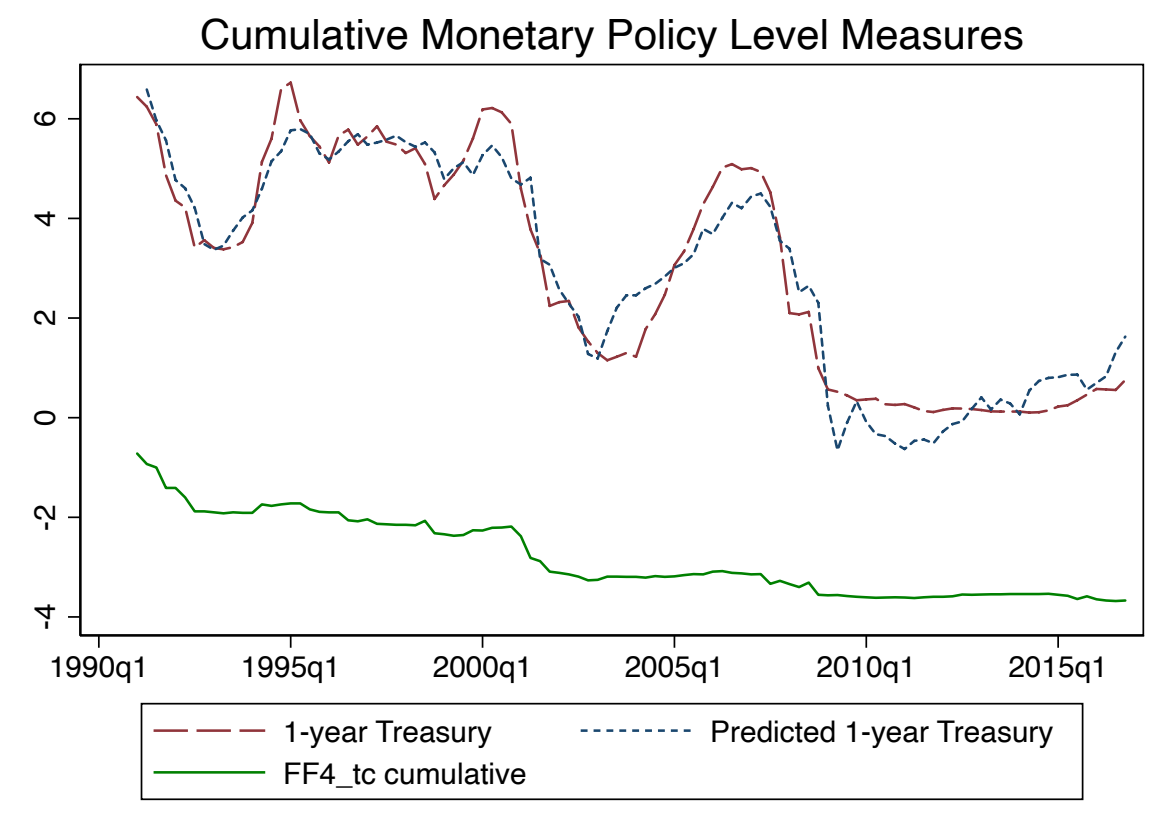


Figure 4: Firm-level Investment Response

The figure plots impulse responses to a $25 \mathrm{bp}$ increase in the 1-year Treasury rate, estimated using instrumental-variable local projections. The instrument is cumulative high-frequency shocks, each measured as a change in the 3-month ahead Fed Funds future rate in the 30 minutes window around FOMC announcements. The sample includes all FOMC meetings over 1991-2016, except the meeting on September 17, 2001, and covers all firms in the matched CRSP-Compustat sample excluding financial firms, utilities and government. Each point represents the point estimate of the coefficient of the 1-year Treasury $\left(\beta_{1}^{h}\right.$ in Eq. 2$)$ from a 2-SLS regression. All regressions include firm and macro controls, as well as firm $\times$ fiscal quarter fixed effects. The dashed line represents 95\% confidence intervals using heteroscedasticity and autocorrelation robust Driscoll-Kraay standard errors. Intangible firms (tangible firms) are firms with an above-median (below-median) intangible-to-total asset ratio in a given quarter.
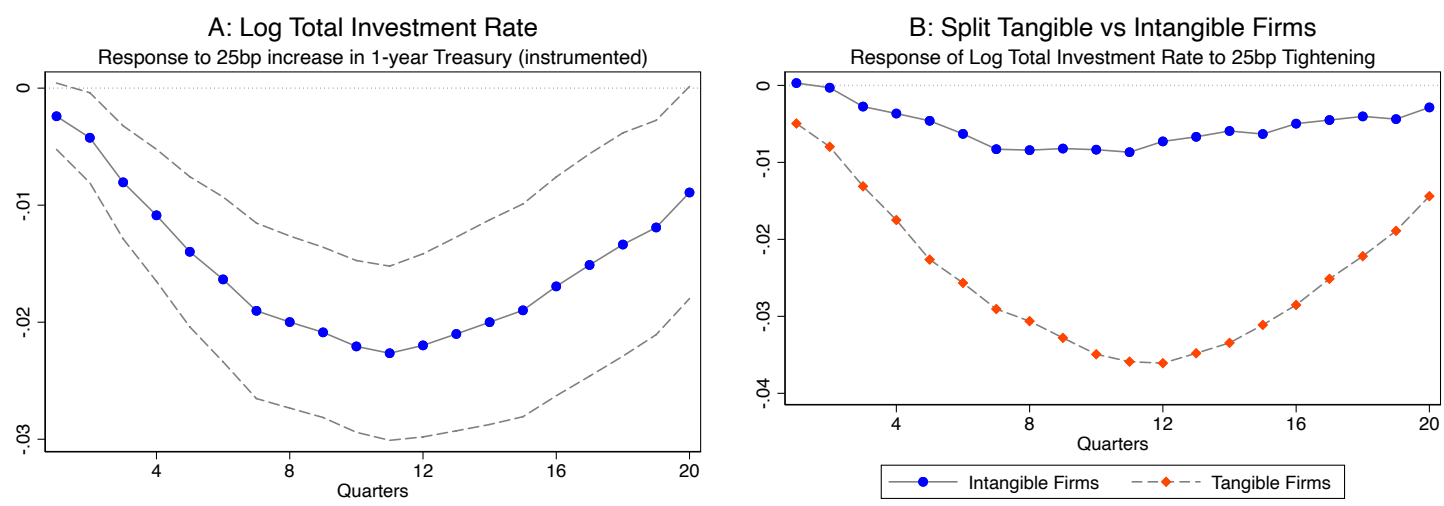

C: Log Tangible Investment Rate

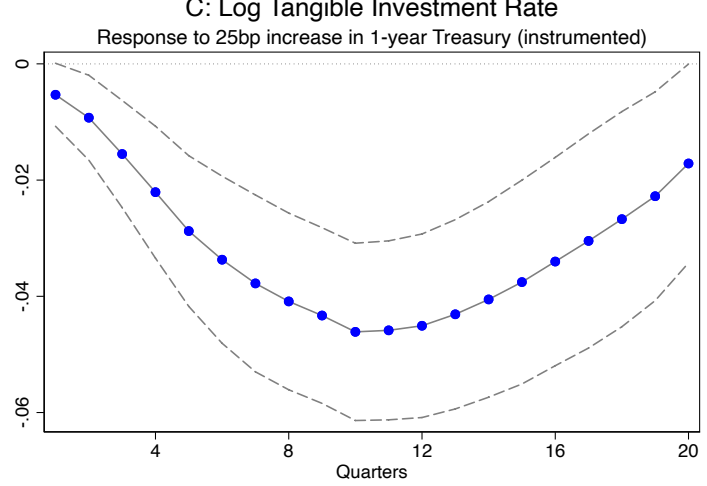

E: Log Tangible-to-Intangible Investment
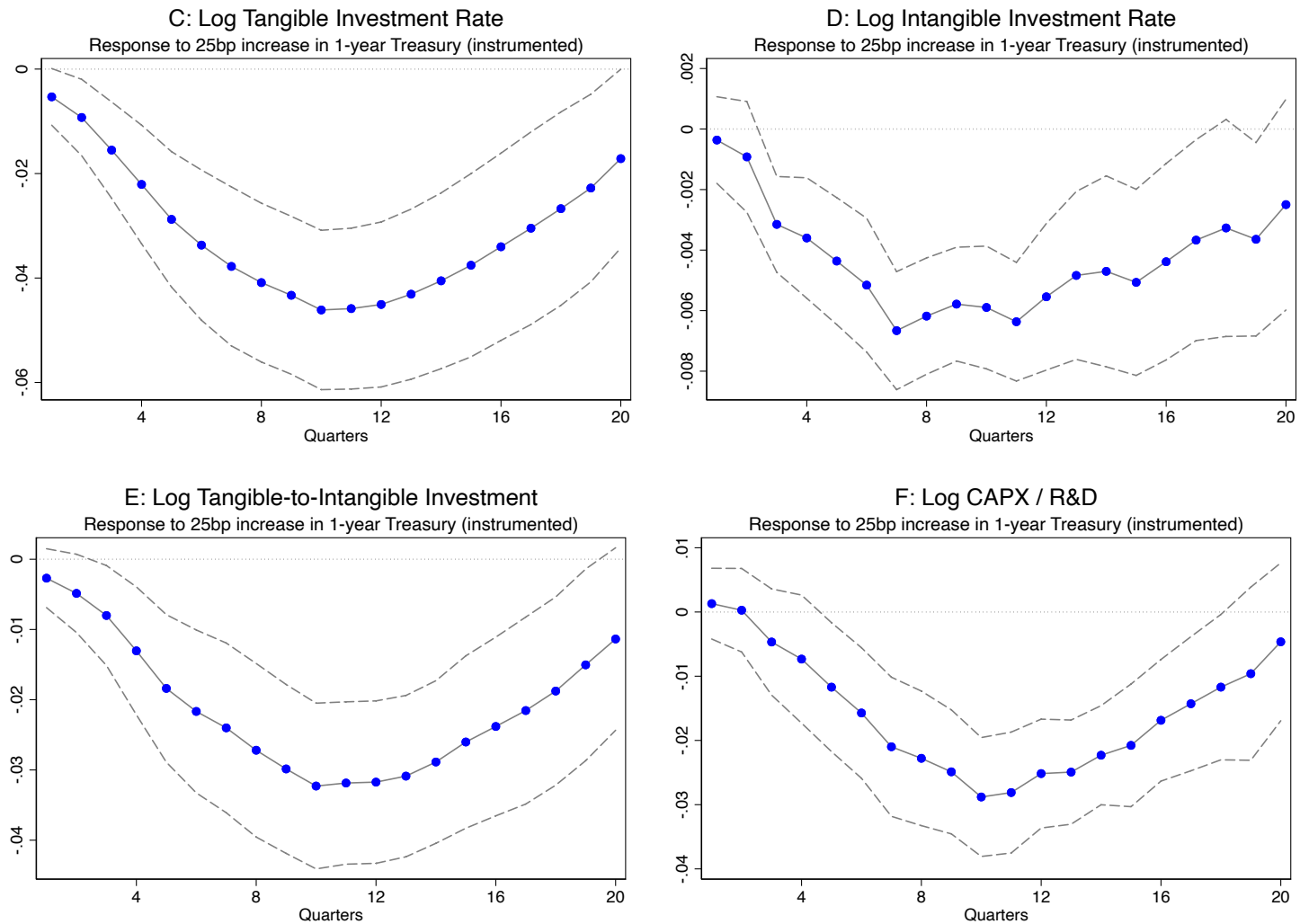

F: Log CAPX / R\&D

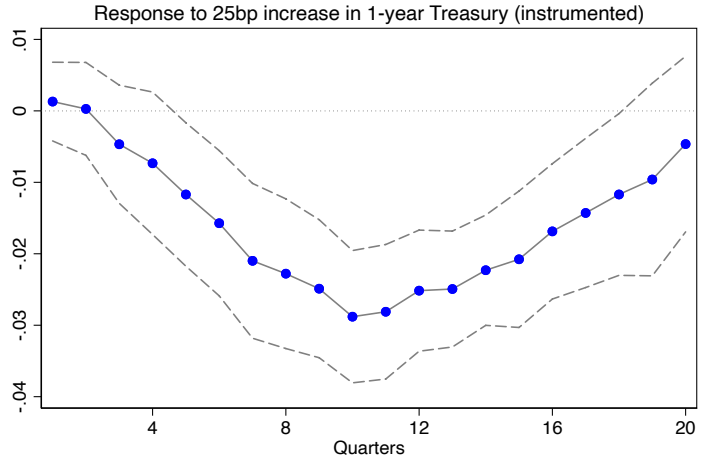


Figure 5: Aggregate Investment Response (NIPA)

This figure plots impulse responses to a 25bp increase in the 1-year Treasury rate, estimated using instrumental-variable local projections. The instrument is the cumulative high-frequency shocks, each measured as a change in the 3-month ahead Fed Funds future rate in the 30 minutes window around FOMC announcements. The sample covers 1991-2016. Each point represents the point estimate of the coefficient of the 1-year Treasury from a 2-SLS regression. All regressions include macro controls log CPI, log industrial production, excess bond premium, and the log of the employment ratio. The dashed line represents $95 \%$ confidence intervals using Newey-West standard errors.
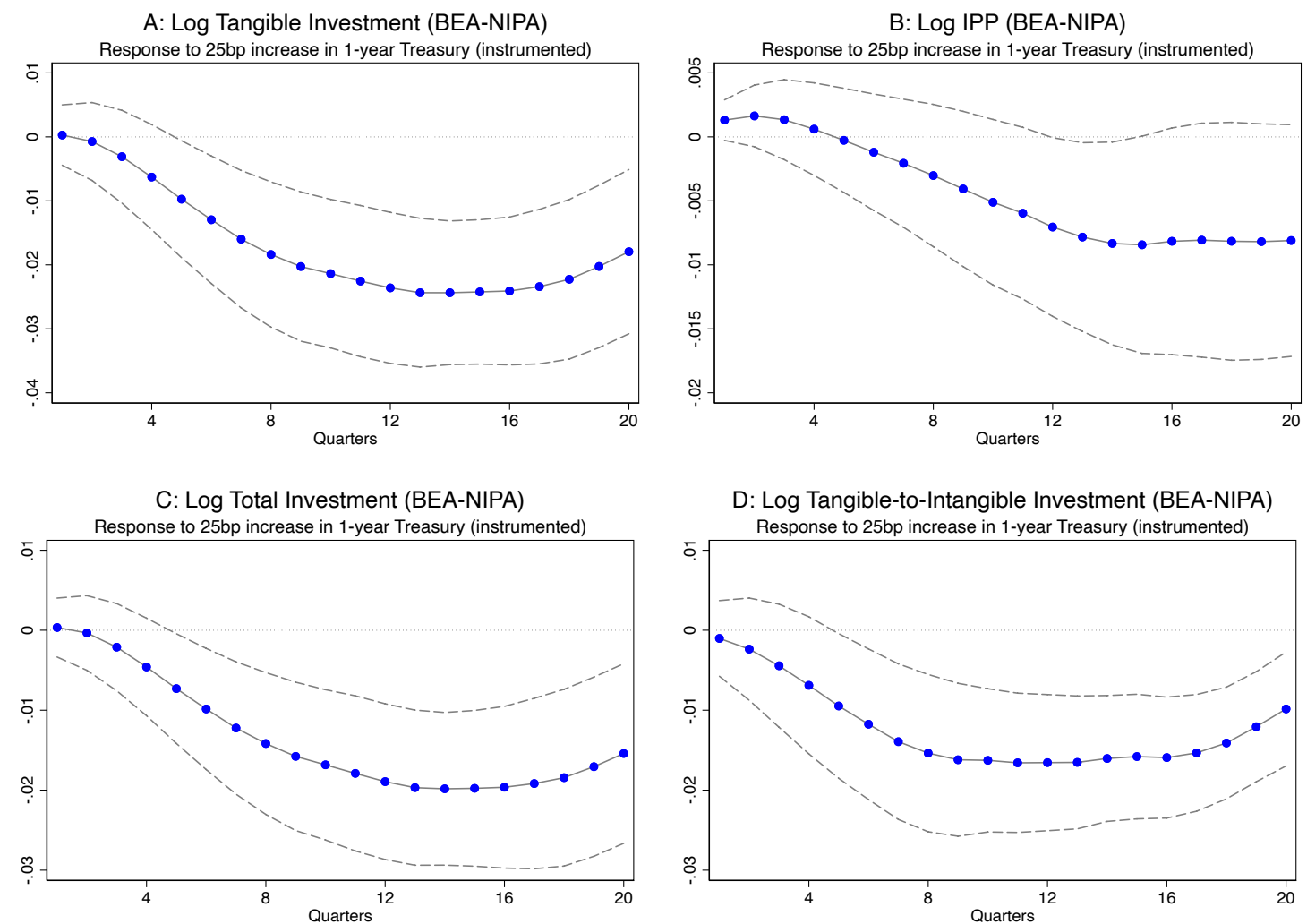
Figure 6: Firm-level Borrowing Response

This figure plots impulse responses to a 25bp increase in the 1-year Treasury rate, estimated using instrumental-variable local projections. The dependent variable is the $h$-quarter change in debt growth, defined as the growth rate of short-term and longterm debt. The instrument is the cumulative high-frequency shocks, each measured as a change in the 3-month ahead Fed Funds future rate in the 30 minutes window around FOMC announcements. The sample includes all FOMC meetings over 1991-2016, except the meeting on September 17, 2001, and covers all firms in the matched CRSP-Compustat sample excluding financial firms, utilities and government. Each point represents the point estimate of the coefficient of the 1-year Treasury ( $\beta_{1}^{h}$ in Eq. 2) from a 2-SLS regression. All regressions include firm and macro controls, as well as firm $\times$ fiscal quarter fixed effects. The dashed line represents 95\% confidence intervals using heteroscedasticity and autocorrelation robust Driscoll-Kraay standard errors. Intangible firms (tangible firms) are firms with an above-median (below-median) intangible-to-total asset ratio in a given quarter.

\section{A: Debt Growth}

Response to 25bp increase in 1-year Treasury (instrumented)

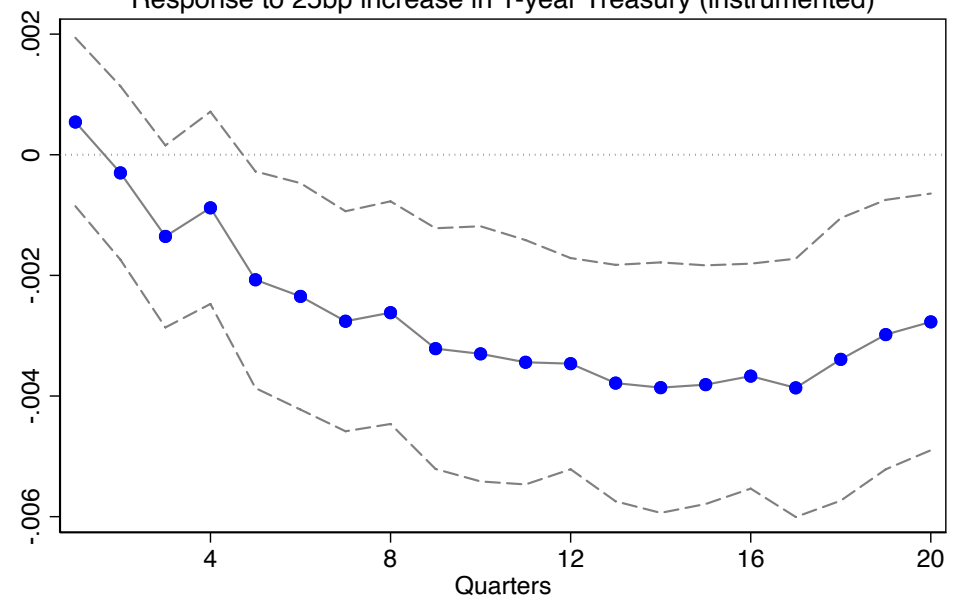

B: Split Tangible vs Intangible Firms

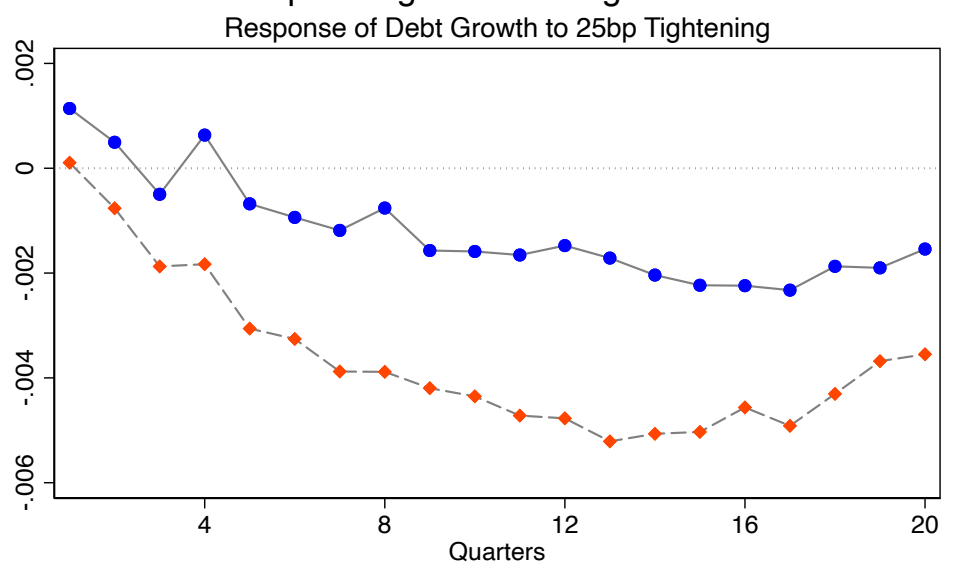

$\bullet$ Intangible Firms $\quad--\downarrow--$ Tangible Firms 
Figure 7: Response of Aggregate Compustat Tangible-to-Intangible Investment - Credit Channel

This figure plots impulse responses of the aggregate log tangible-to-intangible investment rate to a 25bp increase in the 1-year Treasury rate, estimated using instrumental-variable local projections. Each panel represents aggregations within different sub-sets of firms. In panels A and B, young (old) firms are those in the lowest (highest) tercile of the age distribution in a given quarter. In panels $\mathrm{C}$ and $\mathrm{D}$, high cash firms are those in the top tercile in the cash-to-assets distribution in a given quarter, and low cash firms are those in the bottom two terciles. In panels $\mathrm{E}$ and $\mathrm{F}$, high (low) delaycon firms have an above-median (below-median) textual analysis-based delaycon measure of financial constraints of Hoberg and Maksimovic (2015). The instrument is the cumulative high-frequency shocks, each measured as a change in the 3-month ahead Fed Funds future rate in the 30 minutes window around FOMC announcements. The sample includes all FOMC meetings over 1991-2016, except the meeting on September 17, 2001, and covers all firms in the matched CRSP-Compustat sample excluding financial firms, utilities and government. Each point represents the point estimate of the coefficient of the 1-year Treasury from a 2-SLS regression. All regressions include macro controls log CPI, log industrial production, excess bond premium and the log of the employment ratio. The dashed line represents $95 \%$ confidence intervals using Newey-West standard errors.

A: Split by Age

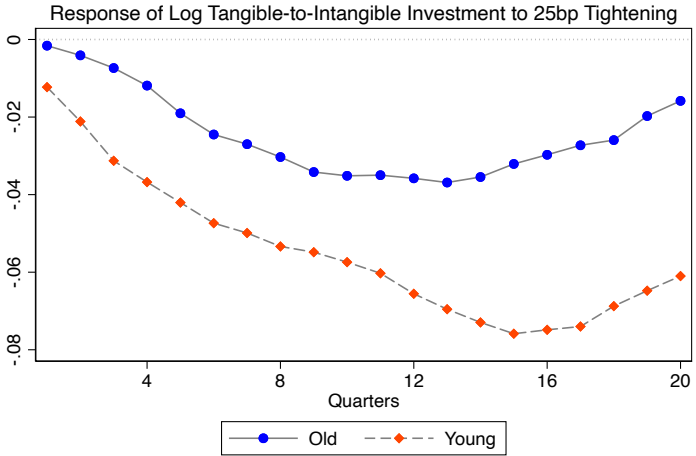

C: Split by Cash Holdings

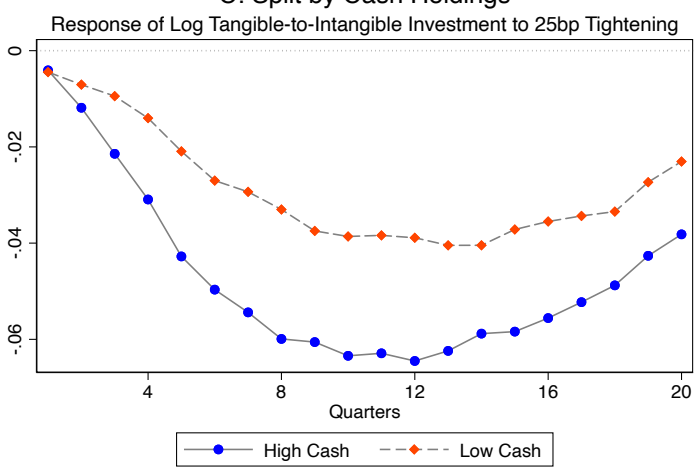

E: Split by Delaycon

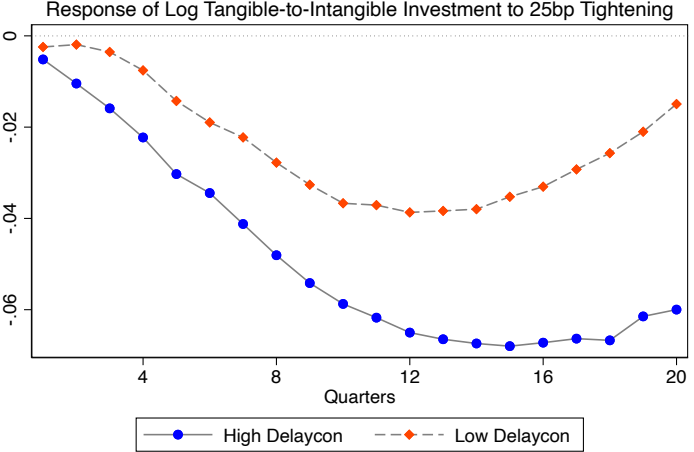

B: Difference Young - Old

Response to 25bp increase in 1-year Treasury (instrumented)

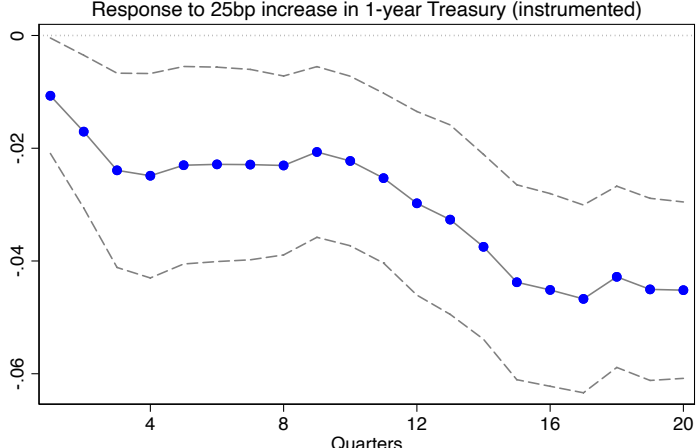

D: Difference High - Low Cash

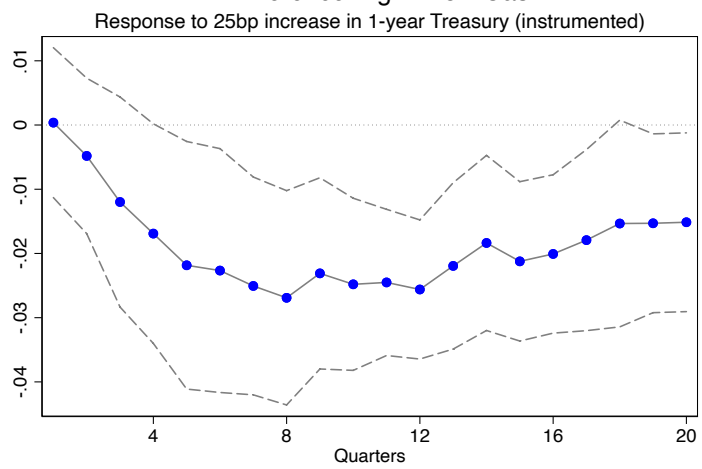

F: Difference High - Low Delaycon

Response to 25bp increase in 1-year Treasury (instrumented)

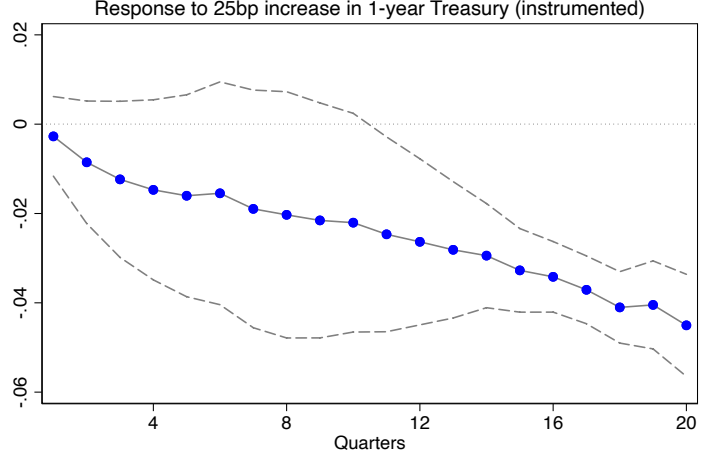


Figure 8: Response of Aggregate Compustat Tangible-to-Intangible Investment - Depreciation Rate Channel

This figure plots impulse responses of the aggregate log tangible-to-intangible investment rate to a 25bp increase in the 1-year Treasury rate, estimated using instrumental-variable local projections. High (low) depreciation gap firms are those with above-median (below-median) difference between tangible and intangible asset depreciation rates. The instrument is the cumulative high-frequency shocks, each measured as a change in the 3-month ahead Fed Funds future rate in the 30 minutes window around FOMC announcements. The sample includes all FOMC meetings over 1991-2016, except the meeting on September 17, 2001, and covers all firms in the matched CRSP-Compustat sample excluding financial firms, utilities and government. Each point represents the point estimate of the coefficient of the 1-year Treasury from a 2-SLS regression. All regressions include macro controls log CPI, log industrial production, excess bond premium and the log of the employment ratio. The dashed line represents $95 \%$ confidence intervals using Newey-West standard errors.

\section{A: Split by Depreciation Gap}

Response of Log Tangible-to-Intangible Investment to 25bp Tightening

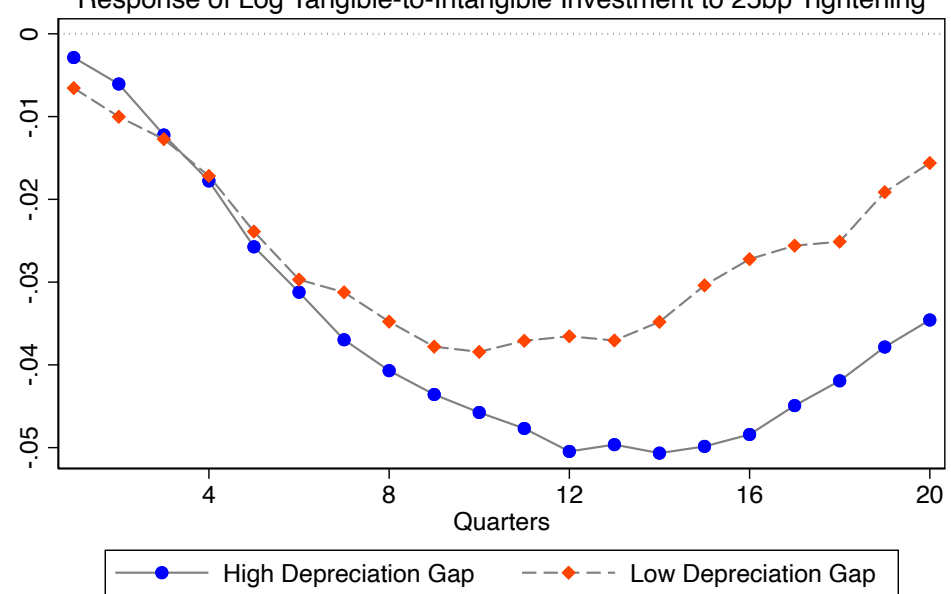

B: Difference High - Low Depreciation Gap

Response to 25bp increase in 1-year Treasury (instrumented)

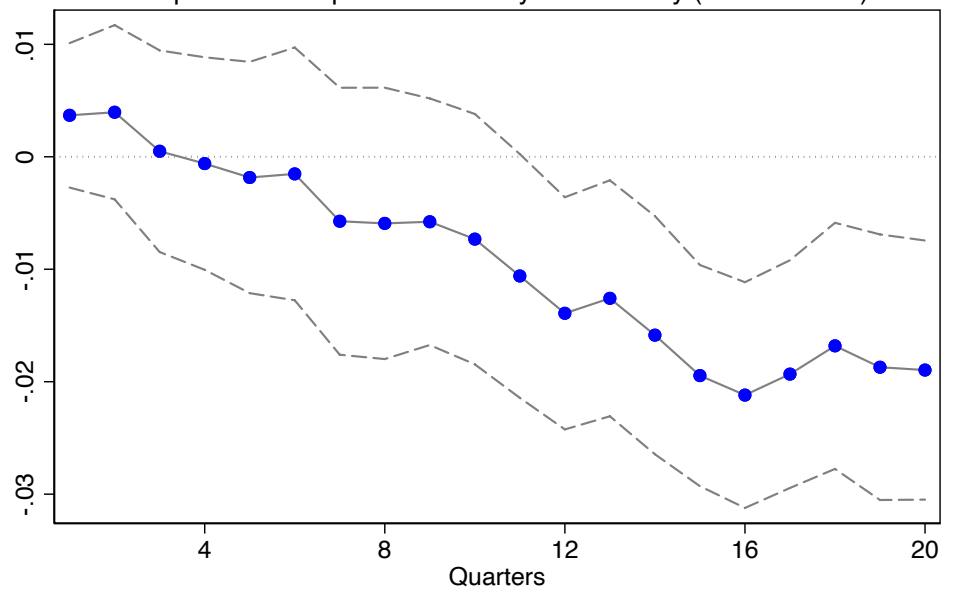


Figure 9: Tangible Investment Response - Sample Splits by Redeployability and Adjustment Cost

This figure plots impulse responses of tangible investment rate to a 25bp increase in the 1-year Treasury rate on different subsamples, estimated using instrumental-variable local projections. High (low) redeployability firms have an asset redeployability estimate from Kim and Kung (2017) above (below) the median in a given quarter. High (low) adjustment cost firms have an investment adjustment cost estimate from Hall (2004) above (below) the median in a given quarter. The instrument is the cumulative high-frequency shocks, each measured as a change in the 3-month ahead Fed Funds future rate in the 30 minutes window around FOMC announcements. The sample includes all FOMC meetings over 1991-2016, except the meeting on September 17, 2001. Each point represents the point estimate of the coefficient of the 1-year Treasury ( $\beta_{1}^{h}$ in Eq. 2) from a 2-SLS regression. All regressions include firm and macro controls, as well as firm $\times$ fiscal quarter fixed effects.

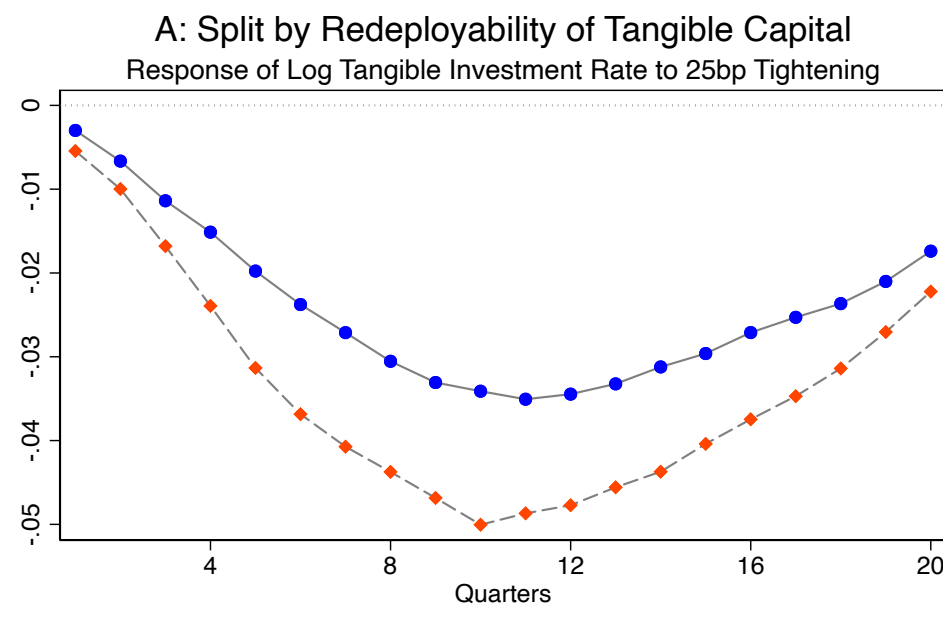

- High Redeployability $\quad--\downarrow--$ Low Redeployability

B: Split by Adjustment Cost of Tangible Capital

Response of Log Tangible Investment Rate to 25bp Tightening

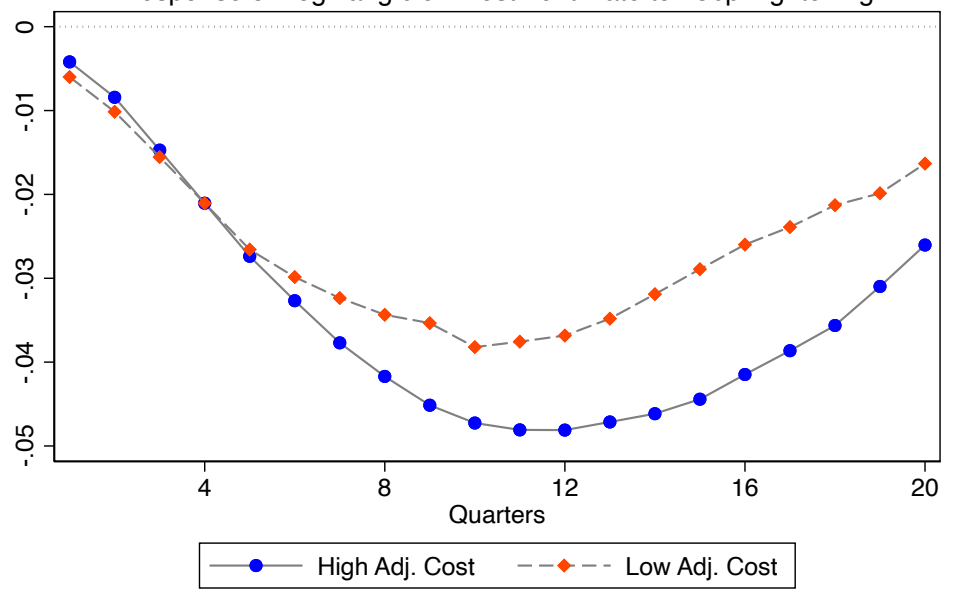




\section{Online Appendix}

Table A1: Definitions of Compustat Variables

\begin{tabular}{|c|c|}
\hline Variable & Definition \\
\hline Physical Capital & PPENT \\
\hline Intangible Capital & $\begin{array}{l}\text { Off-balance sheet intangibles from Peters and Taylor (2017) } \\
\text { + Compustat item INTAN }\end{array}$ \\
\hline Total Capital & Physical Capital + Intangible Capital \\
\hline Intangible Ratio & Intangible Capital / Total Capital \\
\hline Intangible Investment & $\mathrm{XRD}+0.3 \times \mathrm{XSGA}$ \\
\hline Total Investment & CAPX + Intangible Investment \\
\hline Intangible Investment Rate & Intangible Investment / Lagged Intangible Capital \\
\hline Physical Investment Rate & CAPX / Lagged PPENT \\
\hline Total Investment Rate & Total Investment / Lagged Total Capital \\
\hline Total Q & $(\mathrm{CSHO} * \mathrm{PRCC}+$ Total Assets $-\mathrm{CE}) /$ Total Assets \\
\hline Cash & $\mathrm{CHE} / \mathrm{AT}$ \\
\hline Leverage & $(\mathrm{DLTT}+\mathrm{DLC}) / \mathrm{AT}$ \\
\hline Age & Quarters since first observation in sample \\
\hline Delaycon & $\begin{array}{l}\text { Financial constraint measure from Hoberg and Maksimovic } \\
\text { (2015), based on textual analysis of annual reports }\end{array}$ \\
\hline Total Assets & AT + Off-balance sheet intangibles \\
\hline Size & Log of Total Assets \\
\hline Cashflows & OIBDP / Lagged AT \\
\hline Dividend Paid & Dummy whether DVT $>0$ in a given fiscal year \\
\hline
\end{tabular}


Table A2: Definitions of Aggregate Variables

\begin{tabular}{lll}
\multicolumn{1}{c}{ Variable } & \multicolumn{1}{c}{ Definition } & Data Source \\
\hline \hline \multirow{2}{*}{ Physical Investment } & Non-residential investment in structures and equip- & BEA Fixed \\
& Asset Table & 2.3 \\
Intangible Investment & Investment in Intellectual Property Products (IPP) & BEA Fixed \\
& & 2.3 \\
Total Investment & Physical + Intangible Investment & BEA Fixed \\
& & Asset Table \\
1-year Treasury & Interest Rate on 1-year U.S. Treasuries (GS1) & 2.3 \\
CPI & & FRED \\
Employment Ratio & Consumer Price Index (CPALTT01USM661S) & FRED \\
Industrial Production & Industrial Production Index (INDPRO) & FRED \\
Business Investment & Gross private domestic investment: Domestic busi- & FRED \\
ness (W987RC1Q027SBEA) & FRED
\end{tabular}


Table A3: Stock Returns - Robustness to Central Bank Information Shocks from Jarocinski and Karadi (2020) and Intangible Capital Measure from Ewens et al. (2019)

This table documents robustness tests for the baseline Table 2. Panel A decomposes changes in the Fed Funds futures into interest rate shocks (MPshockSign) and central bank information shocks (CBIshockSign), as in Jarocinski and Karadi (2020). Panel B uses the intangible capital stock measure from Ewens et al. (2019) (EPW). The dependent variables are raw and abnormal stock returns on FOMC announcement days. Abnormal returns betas are estimated over a 100-day window before the event date, using CRSP value-weighted index as market benchmark. $\triangle \mathrm{FF} 4$ is the change in the 3-month ahead Fed Futures rate in the 30 minutes around the FOMC announcement. Intangible Ratio is the firm's intangible-to-total asset ratio. Other control variables are defined in Table A1. The sample includes all FOMC meetings over 1991-2016, except the meeting on September 17, 2001, and covers all firms in the matched CRSP-Compustat sample excluding financial firms, utilities and government. Industry fixed effects are based on 4-digit NAICS codes. Standard errors in parentheses clustered by event date and industry. $* * *, * *, *$ indicate significance levels of $1 \%, 5 \%$, and $10 \%$, respectively. Non-interacted coefficients are omitted for brevity.

\begin{tabular}{|c|c|c|c|c|c|}
\hline & $\begin{array}{c}\text { (1) } \\
\text { Raw Return } \\
\end{array}$ & $\begin{array}{c}(2) \\
\text { Raw Return } \\
\end{array}$ & $\begin{array}{c}\text { (3) } \\
\text { Raw Return } \\
\end{array}$ & $\begin{array}{c}(4) \\
\text { Abnormal Return } \\
\end{array}$ & $\begin{array}{c}(5) \\
\text { Abnormal Return } \\
\end{array}$ \\
\hline $\begin{array}{l}\text { Panel A: CBI Shocks } \\
\text { MPshockSign }\end{array}$ & $\begin{array}{c}-7.50^{* * *} \\
(1.75)\end{array}$ & & & & \\
\hline CBIshockSign & $\begin{array}{c}6.05^{* *} \\
(2.90)\end{array}$ & & & & \\
\hline MPshockSign $\times$ Intangible Ratio & & $\begin{array}{c}1.77^{* *} \\
(0.87)\end{array}$ & $\begin{array}{l}1.67^{*} \\
(0.87)\end{array}$ & $\begin{array}{c}1.78^{* *} \\
(0.78)\end{array}$ & $\begin{array}{c}1.61^{* *} \\
(0.79)\end{array}$ \\
\hline CBIshockSign $\times$ Intangible Ratio & & $\begin{array}{l}1.03 \\
(1.24)\end{array}$ & $\begin{array}{l}1.00 \\
(1.30)\end{array}$ & $\begin{array}{c}0.97 \\
(1.32)\end{array}$ & $\begin{array}{c}0.88 \\
(1.36)\end{array}$ \\
\hline $\begin{array}{l}\text { Observations } \\
\text { R-squared }\end{array}$ & $\begin{array}{c}435218 \\
0.030\end{array}$ & $\begin{array}{l}426442 \\
0.243\end{array}$ & $\begin{array}{c}426391 \\
0.263\end{array}$ & $\begin{array}{c}426442 \\
0.143\end{array}$ & $\begin{array}{c}426391 \\
0.164\end{array}$ \\
\hline $\begin{array}{l}\text { Panel B: EPW Intangible } M e \\
\Delta \mathrm{FF} 4\end{array}$ & $\begin{array}{l}\text { sure } \\
\quad-4.36^{* *} \\
(1.77)\end{array}$ & & & & \\
\hline$\Delta \mathrm{FF} 4 \times$ Intangible Ratio $(\mathrm{EPW})$ & & $\begin{array}{c}1.44^{* *} \\
(0.68)\end{array}$ & $\begin{array}{l}1.31^{*} \\
(0.69)\end{array}$ & $\begin{array}{c}1.28^{* *} \\
(0.61)\end{array}$ & $\begin{array}{l}1.08^{*} \\
(0.63)\end{array}$ \\
\hline $\begin{array}{l}\text { Observations } \\
\text { R-squared }\end{array}$ & $\begin{array}{c}451394 \\
0.030\end{array}$ & $\begin{array}{c}442081 \\
0.240\end{array}$ & $\begin{array}{c}442027 \\
0.259\end{array}$ & $\begin{array}{c}442081 \\
0.142\end{array}$ & $\begin{array}{c}442027 \\
0.162\end{array}$ \\
\hline $\begin{array}{l}\text { Industry } \times \text { Event-Date FE } \\
\text { Firm FE } \\
\text { Fiscal Quarter FE } \\
\text { (Interacted) Firm-Level Controls }\end{array}$ & $\begin{array}{l}\text { No } \\
\text { Yes } \\
\text { Yes } \\
\text { Yes }\end{array}$ & $\begin{array}{l}\text { Yes } \\
\text { No } \\
\text { Yes } \\
\text { Yes }\end{array}$ & $\begin{array}{l}\text { Yes } \\
\text { Yes } \\
\text { Yes } \\
\text { Yes }\end{array}$ & $\begin{array}{l}\text { Yes } \\
\text { No } \\
\text { Yes } \\
\text { Yes }\end{array}$ & $\begin{array}{l}\text { Yes } \\
\text { Yes } \\
\text { Yes } \\
\text { Yes }\end{array}$ \\
\hline
\end{tabular}


Table A4: Correlation Table

This table reports correlations between selected variables in the quarterly firm-level data. The sample includes all firms in the matched CRSP-Compustat sample except financial firms, utilities and government. Variable definitions are given in Table A1.

\begin{tabular}{lccccc}
\hline \hline & Age & Cash & Delaycon & Depr. Gap & Redeployability \\
\hline Age & 1.000 & & & & \\
Cash & -0.122 & 1.000 & & & \\
Delaycon & -0.157 & 0.145 & 1.000 & & \\
Depreciation Gap & -0.021 & -0.082 & -0.067 & 1.000 & \\
Redeployability & -0.092 & -0.070 & 0.012 & -0.243 & 1.000 \\
Adjustment Costs & 0.007 & 0.037 & 0.008 & 0.031 & -0.056 \\
\hline \hline
\end{tabular}


Table A5: Stock Returns Around FOMC Meetings - Sample Splits by Firm Age

This table presents a more complete output of Table 4panel A. Young (middle-ages, old) firms are defined as those in the lowest (middle, highest) tercile of the age distribution in a given quarter. The dependent variables are raw and abnormal stock returns on FOMC announcement days. Abnormal returns betas are estimated over a 100-day window before the event date, using CRSP value-weighted index as market benchmark. $\triangle \mathrm{FF} 4$ is the change in the 3-month ahead Fed Futures rate in the 30 minutes around the FOMC announcement. Intangible Ratio is the firm's intangible-to-total asset ratio. Other control variables are defined in Table A1. The sample includes all FOMC meetings over 1991-2016, except the meeting on September 17, 2001, and covers all firms in the matched CRSP-Compustat sample excluding financial firms, utilities and government. Industry fixed effects are based on 4-digit NAICS codes. Standard errors in parentheses are clustered by event date and industry. ***, **,* indicate significance levels of $1 \%, 5 \%$, and $10 \%$, respectively. Non-interacted coefficients are omitted for brevity.

\begin{tabular}{|c|c|c|c|c|c|c|}
\hline & \multicolumn{2}{|c|}{ Young } & \multicolumn{2}{|c|}{ Middle-Aged } & \multicolumn{2}{|c|}{ Old } \\
\hline & $\begin{array}{c}(1) \\
\text { Raw Return }\end{array}$ & $\begin{array}{c}(2) \\
\text { Abn. Return }\end{array}$ & $\begin{array}{c}(3) \\
\text { Raw Return }\end{array}$ & $\begin{array}{c}(4) \\
\text { Abn. Return }\end{array}$ & $\begin{array}{c}(5) \\
\text { Raw Return }\end{array}$ & $\begin{array}{c}(6) \\
\text { Abn. Return }\end{array}$ \\
\hline$\Delta \mathrm{FF} 4 \times$ Intangible Ratio & $\begin{array}{c}3.93^{* *} \\
(1.64)\end{array}$ & $\begin{array}{c}3.26^{* *} \\
(1.40)\end{array}$ & $\begin{array}{c}1.56 \\
(0.95)\end{array}$ & $\begin{array}{c}1.96^{*} \\
(1.10)\end{array}$ & $\begin{array}{c}0.98 \\
(1.57)\end{array}$ & $\begin{array}{c}0.44 \\
(1.48)\end{array}$ \\
\hline$\Delta \mathrm{FF} 4 \times \log$ Age & $\begin{array}{c}0.17 \\
(0.66)\end{array}$ & $\begin{array}{l}-0.35 \\
(0.81)\end{array}$ & $\begin{array}{c}0.54 \\
(0.71)\end{array}$ & $\begin{array}{l}-0.29 \\
(0.61)\end{array}$ & $\begin{array}{c}1.34 \\
(1.01)\end{array}$ & $\begin{array}{c}0.62 \\
(0.97)\end{array}$ \\
\hline$\Delta \mathrm{FF} 4 \times$ Total $\mathrm{Q}$ & $\begin{array}{l}-0.35 \\
(0.55)\end{array}$ & $\begin{array}{l}-0.054 \\
(0.47)\end{array}$ & $\begin{array}{l}-0.56 \\
(0.46)\end{array}$ & $\begin{array}{c}0.22 \\
(0.23)\end{array}$ & $\begin{array}{l}-0.73 \\
(0.53)\end{array}$ & $\begin{array}{r}-0.073 \\
(0.37)\end{array}$ \\
\hline$\Delta \mathrm{FF} 4 \times$ Cash & $\begin{array}{c}-5.75^{* * * *} \\
(1.75)\end{array}$ & $\begin{array}{l}-1.15 \\
(1.31)\end{array}$ & $\begin{array}{c}-5.20^{* * *} \\
(1.46)\end{array}$ & $\begin{array}{c}-2.62^{* *} \\
(1.31)\end{array}$ & $\begin{array}{l}0.098 \\
(3.69)\end{array}$ & $\begin{array}{c}2.42 \\
(2.75)\end{array}$ \\
\hline$\Delta \mathrm{FF} 4 \times$ Leverage & $\begin{array}{c}0.96 \\
(1.46)\end{array}$ & $\begin{array}{r}-0.068 \\
(1.26)\end{array}$ & $\begin{array}{l}-1.20 \\
(1.41)\end{array}$ & $\begin{array}{c}-2.26^{* *} \\
(1.09)\end{array}$ & $\begin{array}{l}-0.40 \\
(1.26)\end{array}$ & $\begin{array}{l}-1.34 \\
(1.55)\end{array}$ \\
\hline$\Delta \mathrm{FF} 4 \times$ Cashflows & $\begin{array}{l}-18.5^{*} \\
(10.6)\end{array}$ & $\begin{array}{l}-19.6 \\
(12.5)\end{array}$ & $\begin{array}{l}-4.12 \\
(11.4)\end{array}$ & $\begin{array}{l}-4.61 \\
(10.6)\end{array}$ & $\begin{array}{c}4.95 \\
(13.5)\end{array}$ & $\begin{array}{c}6.50 \\
(11.8)\end{array}$ \\
\hline$\Delta \mathrm{FF} 4 \times \mathrm{ROA}$ & $\begin{array}{c}25.9^{* *} \\
(11.3)\end{array}$ & $\begin{array}{c}17.9 \\
(11.2)\end{array}$ & $\begin{array}{l}-11.9 \\
(14.9)\end{array}$ & $\begin{array}{l}-11.2 \\
(12.1)\end{array}$ & $\begin{array}{l}-3.06 \\
(10.5)\end{array}$ & $\begin{array}{l}-7.33 \\
(9.91)\end{array}$ \\
\hline$\Delta \mathrm{FF} 4 \times \log$ Size & $\begin{array}{l}-0.97^{*} \\
(0.54)\end{array}$ & $\begin{array}{l}-0.17 \\
(0.31)\end{array}$ & $\begin{array}{l}-0.46 \\
(0.38)\end{array}$ & $\begin{array}{c}0.15 \\
(0.24)\end{array}$ & $\begin{array}{c}-0.55^{* *} \\
(0.22)\end{array}$ & $\begin{array}{r}-0.036 \\
(0.13)\end{array}$ \\
\hline$\Delta \mathrm{FF} 4 \times$ Dividend Paid & $\begin{array}{c}0.56 \\
(0.70)\end{array}$ & $\begin{array}{l}-0.14 \\
(0.70)\end{array}$ & $\begin{array}{c}0.68 \\
(0.44)\end{array}$ & $\begin{array}{l}-0.078 \\
(0.43)\end{array}$ & $\begin{array}{c}0.85 \\
(0.69)\end{array}$ & $\begin{array}{c}0.13 \\
(0.55)\end{array}$ \\
\hline Observations & 122605 & 122605 & 135796 & 135796 & 136265 & 136265 \\
\hline R-squared & 0.404 & 0.329 & 0.378 & 0.300 & 0.391 & 0.286 \\
\hline Industry $\times$ Event-Date FE & Yes & Yes & Yes & Yes & Yes & Yes \\
\hline Firm $\times$ Fiscal-Quarter FE & Yes & Yes & Yes & Yes & Yes & Yes \\
\hline
\end{tabular}


Figure A1: Response of Other Macro Variables

This figure plots impulse responses of a number of macroeconomic variables to a 25bp increase in the 1-year Treasury rate, estimated using instrumental-variable local projections. The instrument is the cumulative high-frequency shocks, each measured as a change in the 3-month ahead Fed Funds future rate in the 30 minutes window around FOMC announcements. The sample covers 1991-2016. Each point represents the point estimate from a 2-SLS regression of the change in the respective dependent variable on the 1-year Treasury rate. All regressions include macro controls log CPI, log industrial production, the excess bond premium, and the log of the employment ratio (excluding the respective dependent variable). The dashed line represents $95 \%$ confidence intervals using Newey-West standard errors.

A: Log Industrial Production

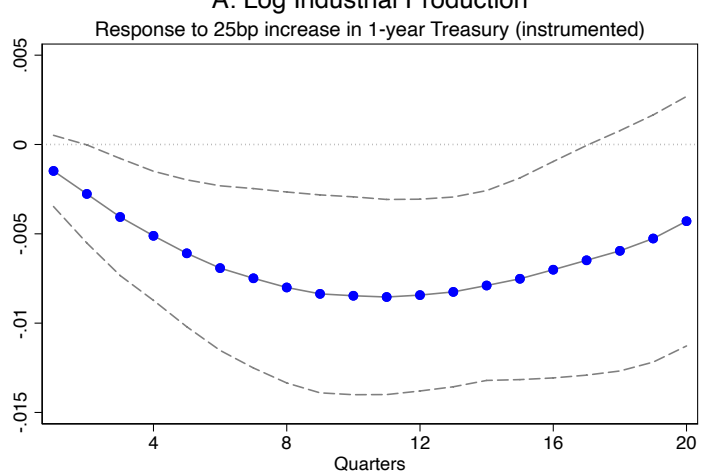

C: Log CPI

Response to 25bp increase in 1-year Treasury (instrumented)

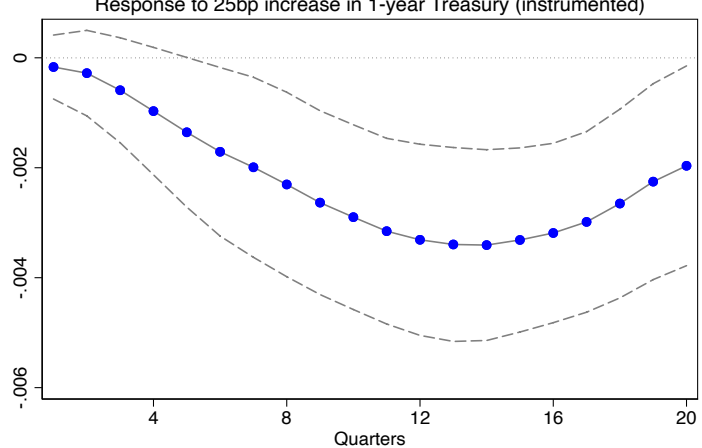

B: Log Employment Ratio

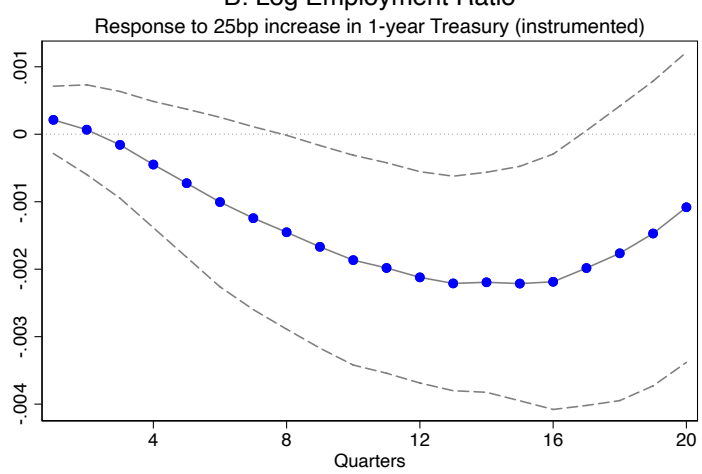

D: Excess Bond Premium

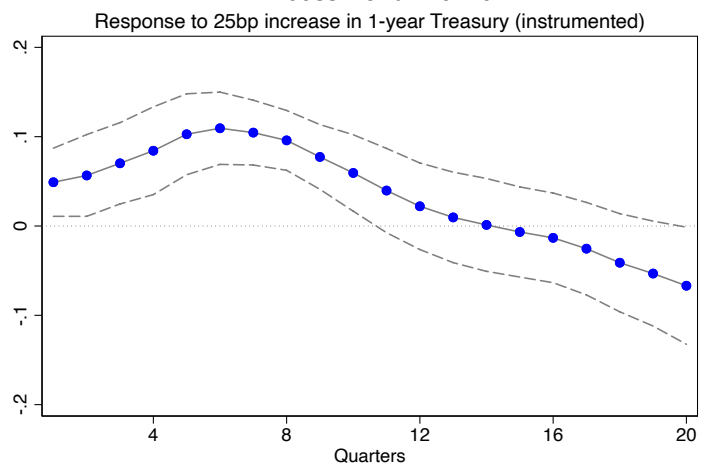

E: Log Business Investment

Response to 25bp increase in 1-year Treasury (instrumented)

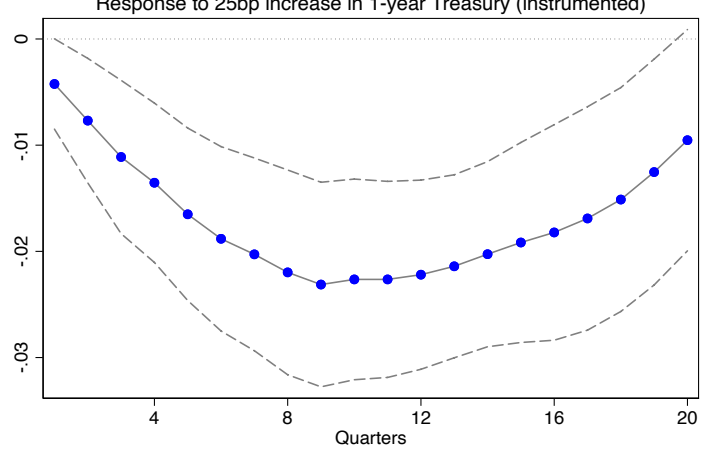


Figure A2: Aggregate Investment Response calculated from Compustat Firm-Level Data

This figure plots impulse responses to a 25bp increase in the 1-year Treasury rate, estimated using instrumental-variable local projections. The instrument is the cumulative high-frequency shocks, each measured as a change in the 3-month ahead Fed Funds future rate in the 30 minutes window around FOMC announcements. The sample includes all FOMC meetings over 1991-2016, except the meeting on September 17, 2001, and covers all firms in the matched CRSP-Compustat sample excluding financial firms, utilities and government. Each point represents the point estimate of the coefficient of the 1-year Treasury from a 2-SLS regression. All regressions include macro controls log CPI, log industrial production, the excess bond premium, and the log of the employment ratio. The dashed line represents $95 \%$ confidence intervals using Newey-West standard errors.

A: Log Tangible Investment Rate (agg.)

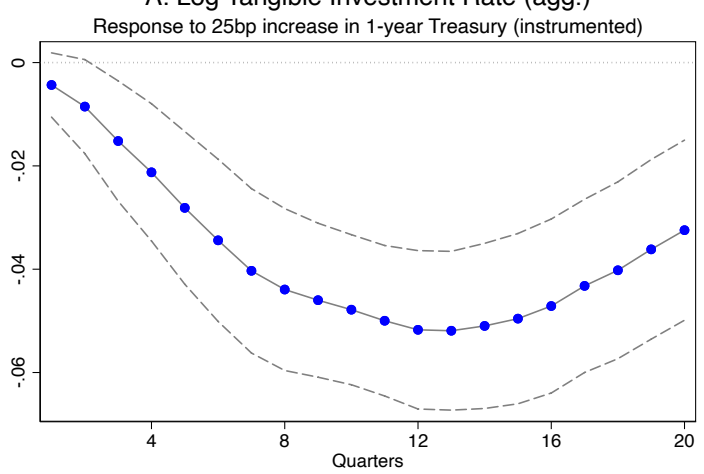

C: Log Total Investment Rate (agg.)

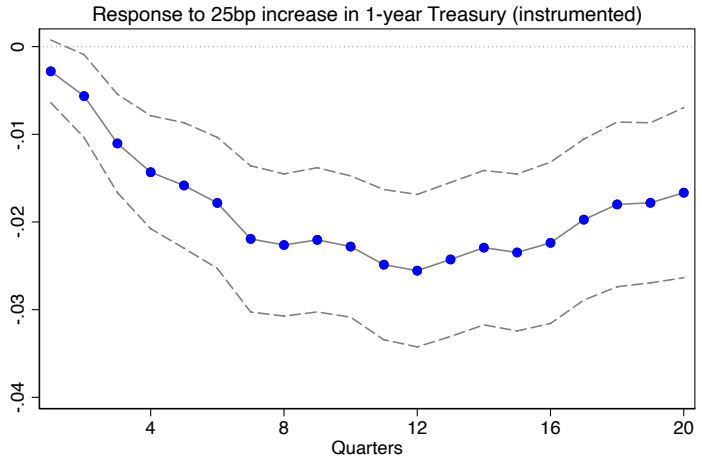

B: Log Intangible Investment Rate (agg.)

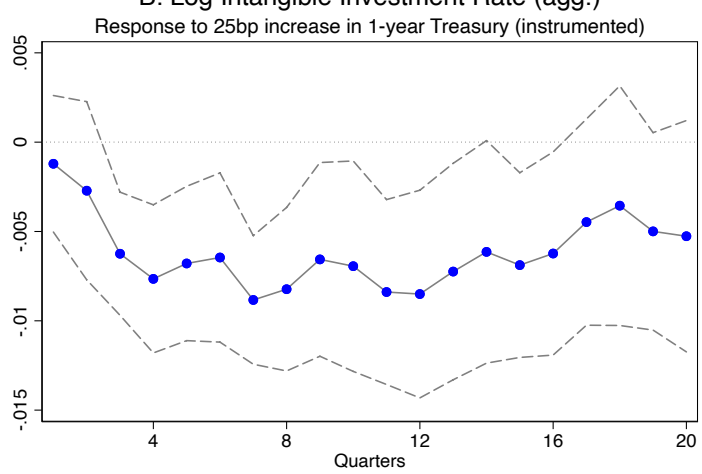

D: Log Tangible-to-Intangible Investment (agg.) Response to $25 \mathrm{bp}$ increase in 1-year Treasury (instrumented)

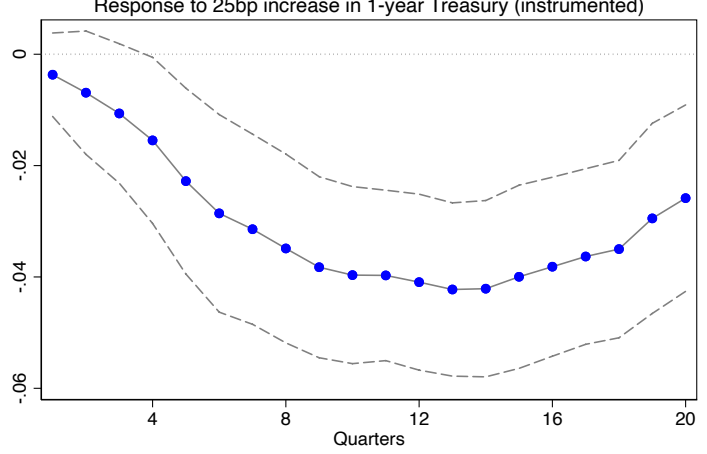


Figure A3: Depreciation Rates and Intangible Investment: An Illustration

The figure illustrates why, under the assumptions of Section 4.2, a given change in interest rates has a smaller effect on investment if asset depreciation rate are higher. The figure plots the relationship between the user cost of capital and investment. In a standard Neoclassical framework with a concave production function $F(K)$, firms scale investment $I$ up to the point where the the marginal product of capital, $M P K(I)=F^{\prime}(K)$, is equal to the user cost of capital, which is the sum of the interest rate $r$ and the depreciation rate $\delta: M P K(I)=r+\delta$. This condition implicitly defines a function $I(r, \delta)$. Since $M P K^{\prime}(I)=F^{\prime \prime}(K) \leq 0$, an increase in interest rates decreases investment, i.e. $\partial I(r, \delta) / \partial r \leq 0$. On the x-axis, the points $I_{T A N}$ and $I_{I N T}$ mark investment under the interest rate $r$ and depreciation rates $\delta_{T A N}$ and $\delta_{I N T}$ with $\delta_{T A N}>\delta_{I N T}$. Consider the effect of an interest rate increase from $r$ to $r^{\prime}>r$. Since $M P K$ is decreasing, a higher interest rate leads to lower investment: a reduction from $I_{T A N}$ to $I_{T A N}^{\prime}$ and from $I_{I N T}$ to $I_{I N T}^{\prime}$. At the same time, the the investment reduction from $I_{T A N}$ to $I_{T A N}^{\prime}$ is larger than that from $I_{I N T}$ to $I_{I N T}^{\prime}$. This is because $\delta_{T A N}>\delta_{I N T}$ and $M P K$ is convex (which holds for standard production functions such as Cobb-Douglas). Thus, a given increase in interest rates has a relatively smaller effect on the user cost of capital if depreciation rates are higher.

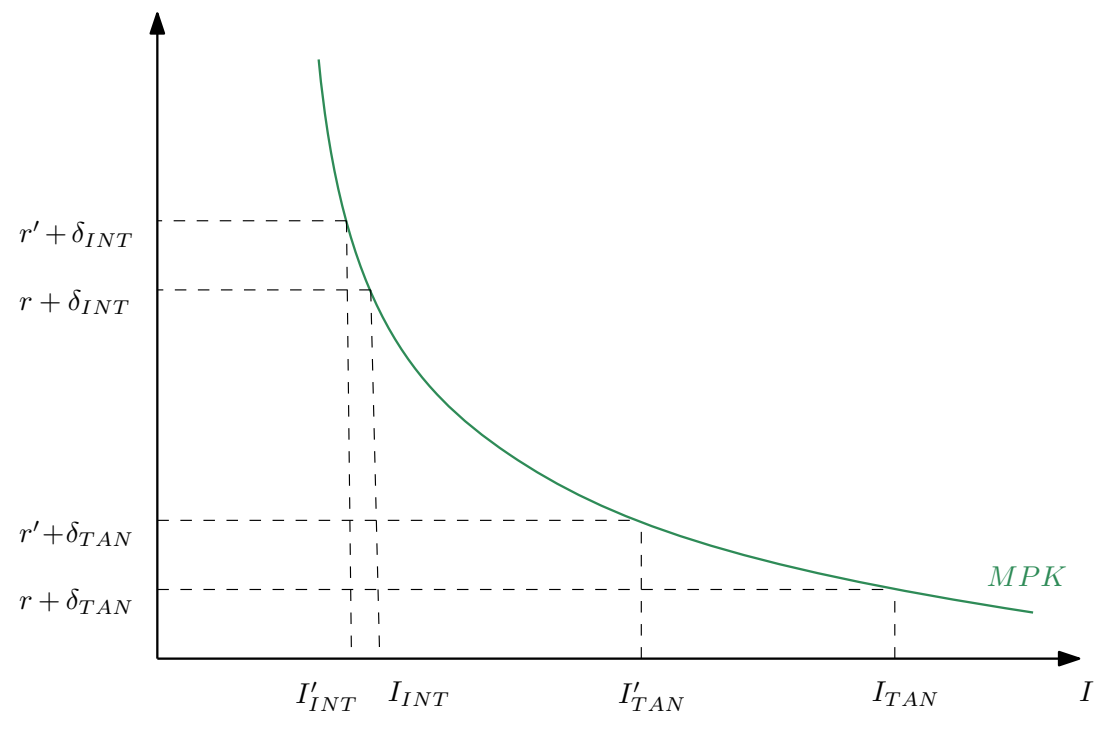




\section{References}

Bahaj, S. A., A. Foulis, and G. Pinter (2020). Home values and firm behaviour. American Economic Review, forthcoming.

Bates, T. W., K. M. Kahle, and R. M. Stulz (2009). Why do us firms hold so much more cash than they used to? Journal of Finance 64(5), 1985-2021.

Bekaert, G., M. Hoerova, and M. L. Duca (2013). Risk, uncertainty and monetary policy. Journal of Monetary Economics 60(7), 771-788.

Benmelech, E. and N. K. Bergman (2009). Collateral pricing. Journal of Financial Economics 91 (3), 339-360.

Bernanke, B. S., M. Gertler, and S. Gilchrist (1999). The financial accelerator in a quantitative business cycle framework. Handbook of Macroeconomics 1, 1341-1393.

Bernanke, B. S. and K. N. Kuttner (2005). What explains the stock market's reaction to federal reserve policy? Journal of Finance 60(3), 1221-1257.

Bloom, N. (2009). The impact of uncertainty shocks. Econometrica 77(3), 623-685.

Brown, J. R., S. M. Fazzari, and B. C. Petersen (2009). Financing innovation and growth: Cash flow, external equity, and the 1990s r\&d boom. Journal of Finance 64(1), 151-185.

Brown, J. R., G. Martinsson, and B. C. Petersen (2013). Law, stock markets, and innovation. Journal of Finance 68(4), 1517-1549.

Caggese, A. and A. Pérez-Orive (2020). How stimulative are low real interest rates for intangible capital?

Carpenter, R. E. and B. C. Petersen (2002). Is the growth of small firms constrained by internal finance? Review of Economics and Statistics 84(2), 298-309.

Cloyne, J., C. Ferreira, M. Froemel, and P. Surico (2018). Monetary policy, corporate finance and investment. NBER Working Paper 25366.

Corrado, C., J. Haskel, and C. Jona-Lasinio (2017). Knowledge spillovers, ict and productivity growth. Oxford Bulletin of Economics and Statistics 79(4), 592-618. 
Corrado, C., J. Haskel, C. Jona-Lasinio, and M. Iommi (2016). Intangible investment in the EU and US before and since the Great Recession and its contribution to productivity growth.

Corrado, C., C. Hulten, and D. Sichel (2009). Intangible capital and us economic growth. Review of Income and Wealth 55(3), 661-685.

Corrado, C. A. and C. R. Hulten (2010). How do you measure a "technological revolution"? American Economic Review 100(2), 99-104.

Crouzet, N. and J. C. Eberly (2019). Understanding weak capital investment: The role of market concentration and intangibles. NBER Working Paper 25869.

Dell'Ariccia, G., D. Kadyrzhanova, C. Minoiu, and L. Ratnovski (2020). Bank lending in the knowledge economy. ECB Working Paper 2429.

Döttling, R., T. Ladika, and E. C. Perotti (2020). Creating intangible capital.

Eisfeldt, A. L. and D. Papanikolaou (2013). Organization capital and the cross-section of expected returns. Journal of Finance 68(4), 1365-1406.

Ewens, M., R. Peters, and S. Wang (2019). Measuring intangible capital with market prices. NBER Working Paper 25960.

Falato, A., D. Kadyrzhanova, J. Sim, and R. Steri (2018). Rising intangible capital, shrinking debt capacity, and the us corporate savings glut.

Farre-Mensa, J. and A. Ljungqvist (2016). Do measures of financial constraints measure financial constraints? Review of Financial Studies 29(2), 271-308.

Gertler, M. and S. Gilchrist (1994). Monetary policy, business cycles, and the behavior of small manufacturing firms. Quarterly Journal of Economics 109(2), 309-340.

Gertler, M. and P. Karadi (2015). Monetary policy surprises, credit costs, and economic activity. American Economic Journal: Macroeconomics 7(1), 44-76.

Gilchrist, S. and E. Zakrajšek (2012). Credit spreads and business cycle fluctuations. American Economic Review 102(4), 1692-1720. 
Gurkaynak, R. S., B. P. Sack, and E. T. Swanson. Do actions speak louder than words? the response of asset prices to monetary policy actions and statements. International Journal of Central Banking 1(1), 55-93.

Gutiérrez, G. and T. Philippon (2017). Investmentless growth: An empirical investigation. Brookings Papers on Economic Activity 2017(2), 89-190.

Hadlock, C. J. and J. R. Pierce (2010). New evidence on measuring financial constraints: Moving beyond the kz index. Review of Financial Studies 23(5), 1909-1940.

Hall, R. E. (2004). Measuring factor adjustment costs. Quarterly Journal of Economics 119(3), 899-927.

Haskel, J. (2020). Monetary policy in the intangible economy.

Hoberg, G. and V. Maksimovic (2015). Redefining financial constraints: A text-based analysis. Review of Financial Studies 28(5), 1312-1352.

Jarocinski, M. and P. Karadi (2020). Deconstructing monetary policy surprises: the role of information shocks. American Economic Journal: Macroeconomics 12(2), 1-43.

Jeenas, P. (2018a). Firm balance sheet liquidity, monetary policy shocks, and investment dynamics.

Jeenas, P. (2018b). Monetary policy shocks, financial structure, and firm activity: A panel approach.

Jordà, Ò. (2005). Estimation and inference of impulse responses by local projections. American Economic Review 95(1), 161-182.

Kashyap, A. K., O. A. Lamont, and J. C. Stein (1994). Credit conditions and the cyclical behavior of inventories. Quarterly Journal of Economics 109(3), 565-592.

Kashyap, A. K. and J. C. Stein (1995). The impact of monetary policy on bank balance sheets. CarnegieRochester Conference Series on Public Policy 42, 151-195.

Kim, H. and H. Kung (2017). The asset redeployability channel: How uncertainty affects corporate investment. Review of Financial Studies 30(1), 245-280.

Kiyotaki, N. and J. Moore (1997). Credit cycles. Journal of Political Economy 105(2), 211-248.

Kuttner, K. N. (2001). Monetary policy surprises and interest rates: Evidence from the fed funds futures market. Journal of Monetary Economics 47(3), 523-544. 
Li, W. C. (2012). Depreciation of business R\&D capital. Bureau of Economic Analysis/National Science Foundation RED Satellite Account Paper.

Li, W. C. and B. H. Hall (2016). Depreciation of business R\&D capital. Review of Income and Wealth.

Loumioti, M. (2012). The use of intangible assets as loan collateral. Available at SSRN 1748675.

Majd, S. and R. S. Pindyck (1985). Time to build, option value, and investment decisions. NBER Working Paper 1654.

Mann, W. (2018). Creditor rights and innovation: Evidence from patent collateral. Journal of Financial Economics 130(1), 25-47.

Ottonello, P. and T. Winberry (2018). Financial heterogeneity and the investment channel of monetary policy. NBER Working Paper 24221.

Peters, R. H. and L. A. Taylor (2017). Intangible capital and the investment-q relation. Journal of Financial Economics 123(2), 251-272.

Rampini, A. A. and S. Viswanathan (2013). Collateral and capital structure. Journal of Financial Economics $109(2), 466-492$.

Roberts, K. and M. L. Weitzman (1981). Funding criteria for research, development, and exploration projects. Econometrica, 1261-1288.

Summers, L. H. (2015). Demand side secular stagnation. American Economic Review 105(5), 60-65.

Sun, Q. and M. Z. Xiaolan (2019). Financing intangible capital. Journal of Financial Economics 133(3), $564-588$. 